\title{
Energy recovery from plastic and biomass waste by means of fluidized bed gasification: A life cycle inventory model
}

\author{
Ardolino, Filomena; Lodato, Concetta; Astrup, Thomas Fruergaard; Arena, Umberto
}

Published in:

Energy

Link to article, DOI:

10.1016/j.energy.2018.09.158

Publication date:

2018

Document Version

Peer reviewed version

Link back to DTU Orbit

Citation (APA):

Ardolino, F., Lodato, C., Astrup, T. F., \& Arena, U. (2018). Energy recovery from plastic and biomass waste by means of fluidized bed gasification: A life cycle inventory model. Energy, (Part B), 299-314.

https://doi.org/10.1016/j.energy.2018.09.158

\section{General rights}

Copyright and moral rights for the publications made accessible in the public portal are retained by the authors and/or other copyright owners and it is a condition of accessing publications that users recognise and abide by the legal requirements associated with these rights.

- Users may download and print one copy of any publication from the public portal for the purpose of private study or research.

- You may not further distribute the material or use it for any profit-making activity or commercial gain

- You may freely distribute the URL identifying the publication in the public portal 


\section{Accepted Manuscript}

Energy recovery from plastic and biomass waste by means of fluidized bed gasification: A life cycle inventory model

Filomena Ardolino, Concetta Lodato, Thomas F. Astrup, Umberto Arena

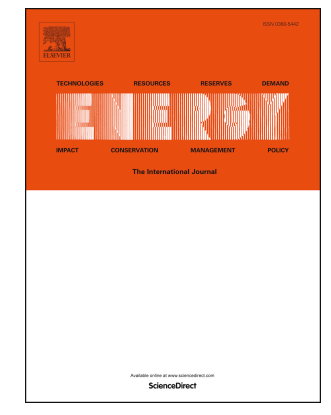

PII:

S0360-5442(18)31930-3

DOI:

10.1016/j.energy.2018.09.158

Reference: EGY 13852

To appear in: Energy

Received Date: 17 July 2018

Revised Date: 19 September 2018

Accepted Date: 23 September 2018

Please cite this article as: Ardolino F, Lodato C, Astrup TF, Arena U, Energy recovery from plastic and biomass waste by means of fluidized bed gasification: A life cycle inventory model, Energy (2018), doi: https://doi.org/10.1016/j.energy.2018.09.158.

This is a PDF file of an unedited manuscript that has been accepted for publication. As a service to our customers we are providing this early version of the manuscript. The manuscript will undergo copyediting, typesetting, and review of the resulting proof before it is published in its final form. Please note that during the production process errors may be discovered which could affect the content, and all legal disclaimers that apply to the journal pertain. 


\title{
ENERGY RECOVERY FROM PLASTIC AND BIOMASS WASTE BY
}

\section{MEANS OF FLUIDIZED BED GASIFICATION: A LIFE CYCLE} INVENTORY MODEL

\author{
Filomena Ardolino ${ }^{1}$, Concetta Lodato ${ }^{2}$, Thomas F. Astrup ${ }^{2}$, Umberto Arena ${ }^{1}$ \\ ${ }^{1}$ Department of Environmental, Biological, Pharmaceutical Sciences and Technologies - University of \\ Campania "Luigi Vanvitelli", Caserta, Italy. \\ ${ }^{2}$ Department of Environmental Engineering, Technical University of Denmark, Bygningstorvet, building 115, \\ 2800 Kgs. Lyngby, Denmark.
}

\section{ABSTRACT}

The study provides for the first time a life cycle inventory model for the fluidized bed gasification of wastes, based on a large amount of high-quality data. All of them have been obtained from a pilot scale fluidized bed gasifier, fed with ten types of waste and biomass, under a wide range of operating conditions. The model refers to commercial scale gasifiers having a "thermal configuration", where the generated syngas is immediately burned downstream of the reactor. Key relationships between process- and waste-specific parameters have been defined. The model quantifies the main inputs and outputs of the gasification process (emissions, energy recovery, ash disposal, resource consumptions), providing high-quality data that could contribute to improve life cycle assessment modelling of waste gasification. Finally, some case studies have been implemented in the EASETECH software to illustrate the model applicability, evaluate the role of main parameters, and compare the environmental performances of gasification power units with that of the European electricity mix. The performances appear highly affected by metal contents in the waste-derived fuels, while the model results to a limited extent are sensitive to the equivalence ratio and the net electrical efficiency of the energy conversion. 


\section{KEYWORDS}

Gasification; Life cycle assessment; EASETECH; Fluidized beds; Plastic waste; Industrial biomass

\section{LIST OF ACRONYMS}

\begin{tabular}{|l|l|l|l|}
\hline APC & Air Pollution Control & LCl & Life Cycle Inventory \\
\hline CC & Conversion Coefficient & LCIA & Life Cycle Impact Assessment \\
\hline CCE & Carbon Conversion Efficiency & LHV & Low Heating Value \\
\hline CGE & Cold Gas Efficiency & MSW & Municipal Solid Waste \\
\hline CTUh & Comparative Toxic Unit for humans & ORC & Organic Rankine Cycle \\
\hline ER & Equivalence Ratio & SNG & Substitute of Natural Gas \\
\hline FBG & Fluidized Bed Gasifier & TC & Transfer Coefficient \\
\hline GHG & Greenhouse Gas & TS & Total Solids \\
\hline GWP & Global Warming Potential & VF & Variation Factor \\
\hline HRSG & Heat Recovery and Steam Generation & VS & Volatile Solids \\
\hline LCA & Life Cycle Assessment & ww & Wet weight \\
\hline
\end{tabular}

\section{INTRODUCTION}

Gasification is a thermochemical conversion process that allows an efficient resource recovery from a wide range of biomass and waste-derived fuels [1]. Currently, it is utilised in more than 100 commercial-scale waste-to-energy plants, fed with the organic fraction of municipal solid waste (MSW) after source-separation of recyclables as well as with residual from specific recycling chains, as those of plastic wastes [2,3]. Gasification converts solid waste materials into a fuel gas, called "syngas", through a series of heterogeneous and homogeneous reactions, taking place in a reducing atmosphere where the gasifying agent can be air, oxygen-enriched air, steam or carbon dioxide $[2,4]$. The obtained syngas contains large amounts of incompletely oxidised products, mainly $\mathrm{CO}$ and $\mathrm{H}_{2}$, together with smaller amounts of $\mathrm{CH}_{4}$. The syngas represents a valuable product that can be used in a wide range of applications, aiming at generation of energy, fuels [5] and drop-in chemicals $[6,7]$. However, the syngas generally contains a range of organic (tar) and inorganic $\left(\mathrm{H}_{2} \mathrm{~S}, \mathrm{HCl}, \mathrm{NH}_{3}, \mathrm{HCN}\right.$ and alkali metals) impurities that may complicate further its 
utilisation and cause operating challenges, such as fouling and slagging of heating surfaces, catalyst poisoning, extra costs for maintenance and unplanned plant shut-downs $[2,5]$.

Fluidization is a promising gasification technology as it permits a high quality gas-solid contact, thereby enabling an efficient mass and heat transfer. The process flexibility of fluidized bed gasifiers (FBGs) is able to accommodate variations in fuel quality, to allow the utilisation of different fluidizing agents, reactor temperatures and gas residence times, to add reagents along the reactor height, and to operate with or without a catalyst $[2,8]$.

Only few attempts can be found in scientific literature of fluidized bed gasification modelling in a life cycle assessment (LCA) perspective, based on high quality (operating or experimental) data. In most cases, only the greenhouse gas emissions [9] and the Global Warming Potential (GWP) [10] have been included. The published LCA studies on gasification can be grouped by different criteria, such as the analysed feedstock, specific reactor technology, final products and selected comparative scenarios. Gasification-based waste-to-energy units for MSW have been compared with other thermal treatments [11] or alternative management strategies $[12,13]$. The environmental performance of biomass gasification has been assessed with reference to different systems for energy production, such as integrated gasification combined cycles [14,15] or combined heat and power plants [16]. In particular, fluidized bed gasification for energy and chemicals production has been assessed for several biomass fuels $[17,18]$ or waste fuels [19], different plant scales [20], or compared with alternative conversion technologies, such as vertical shaft furnace [21] or fixed bed [22]. Other publications have quantified the environmental performance of FBGs aimed at the production and utilisation of gaseous fuels (such as hydrogen [23, 24] and SNG [25-27]) or liquid fuels [28]. A few examples of LCA studies quantifying the environmental effects of FBGs integrated in a material recovery facility [29], a bio-refinery [30], and potential future energy systems [31] exist. 
None of these studies includes a detailed life cycle inventory $(\mathrm{LCl})$ model for the gasification process. As such, the links between the fuel input, conversion and process outputs may be poorly described. In order to provide high-quality input data for LCA modelling of waste gasification, systematic and transparent definition of the inventory data is needed. While several descriptive or predictive models for fluidized bed gasification of waste exist in the scientific literature $[5,8]$, none of these models is able to appropriately represent the waste gasification behaviour, mainly because it is difficult to quantify the crucial catalytic effect of olivine bed particles. The aim of this study is to provide an inventory model for fluidized bed gasification of waste, in order to improve the quality of LCA studies in this field.

To this end, a large amount of experimental data, collected from a pilot scale bubbling fluidized bed gasifier, with a reactor size sufficiently large to avoid scale-up effects, has been used [32]. These data derive from hundreds of hours of operation of the FBG over 10 years, by feeding 10 different waste and biomass fuels [32-38]. The inventory model has been implemented in the EASETECH LCA model and applied to selected case-studies scenarios to illustrate applicability. The specific objectives were: i) define key relationships between FBG input and outputs with respect to relevant process- and waste-specific parameters; ii) define a set of "Substance Transfer Coefficients (TCs)" and a set of "Substance-to-Compound Conversion Coefficients (CCs)" for all of the analysed fuels; iii) implement the defined waste- and process-specific parameters as well as transfer and conversion coefficients into an inventory model; iv) apply this inventory model to selected scenarios in EASETECH for quantification of the environmental impacts; and v) carry out a sensitivity analysis for identification of the most critical model parameters. 


\section{METHODOLOGY}

\subsection{THE FLUIDIZED BED GASIFIER OF REFERENCE}

The pilot scale bubbling fluidized bed gasifier (FBG) utilised for the experimental activity that generated all the inventory data has a maximum thermal output of about $400 \mathrm{~kW}$, which means an input capacity between 30 and $100 \mathrm{~kg} / \mathrm{h}$, depending on the type of feedstock. As mentioned above, the size of the reactor, which has an internal diameter of $0.381 \mathrm{~m}$, allows avoiding any significant scale-up effect, and modelling the performances of larger commercial facilities, as already made in previous studies [38, 39]. During each FBG test, the gasifying agent is injected from the reactor bottom into a bed of olivine particles [40] while the waste is fed by means of an over-bed feeding system. The generated syngas is sent to a cleaning section, composed of a cyclone and a wet scrubber. In all the runs, a double system is utilised for on-line measurements of syngas composition: a set of IR analysers (Horiba VA-3115 for $\mathrm{CO}, \mathrm{CO}_{2}$ and $\mathrm{O}_{2}$, Horiba VA-3001 for $\mathrm{CH}_{4}$ and Teledyne Anal. Instr.-2000 for $\mathrm{H}_{2}$ ), and an Agilent 3000 micro-gas-chromatograph. Each test is carried out under autothermal conditions (i.e. without any thermal assistance by external heaters), and consequently the heat necessary for endothermic gasification reactions is provided by the partial oxidation of the fuel in the gasifier itself and at fixed values of superficial fluidizing velocity and equivalence ratio (ER). The first is defined as the ratio between the volumetric flow rate of the fluidizing agent and the cross-section area of the bed while ER is defined as the ratio between the oxygen flow rate injected into the reactor and that required for the stoichiometric combustion of the solid fuel fed to the reactor. The resulting reactor temperature is a state variable, i.e. the answer of the FBG system to the selected values of design variables, such as ER, waste heating value, and preheating temperature of the fluidizing gas [2].

The implemented thermal FBG model refers to gasification-based waste-to-energy systems of commercial scale. The model assumes air as the fluidizing agent, and olivine as the bed material, 
due to its good performances as tar cracking catalyst during gasification of polyolefin plastic wastes [32] and biomass [34]. Olivine is a neo-silicate of Fe and Mg with a particle density of 2900 $\mathrm{kg} / \mathrm{m}^{3}$, which is assumed to have a particle size range of $200-400 \mu \mathrm{m}$. The model assesses the different behaviours of the selected fuels when the fluidizing velocities and ER range from 0.67 to $0.74 \mathrm{~m} / \mathrm{s}$ and from 0.20 to 0.31 , respectively. A "thermal gasifier" configuration has been chosen: the syngas is dedusted in a cyclone and then burned in a combustor for the production of electricity, while the obtained flue gas is cleaned in an air pollution control (APC) system (Figure 1).

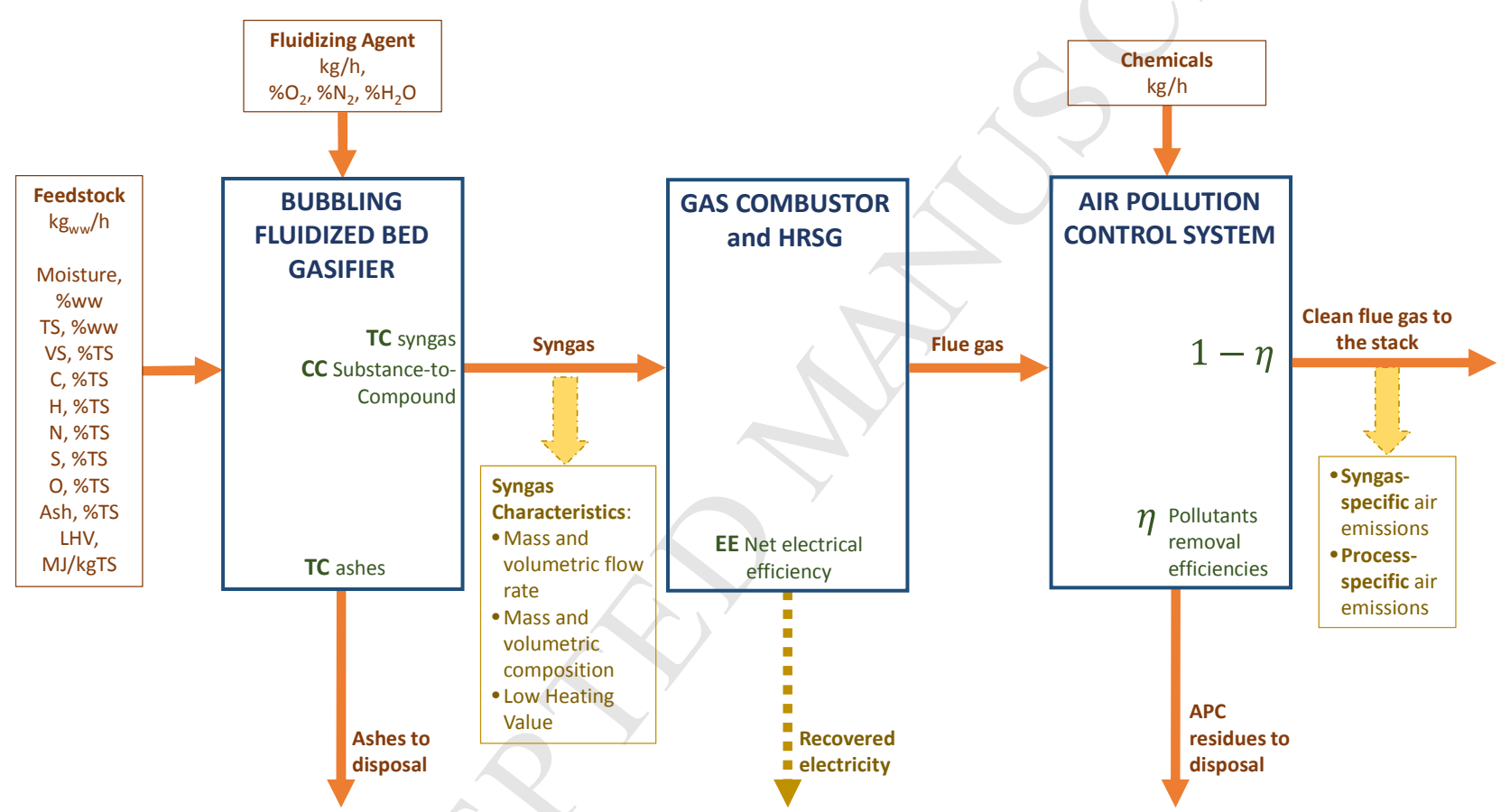

Figure 1. General overview of the fluidized bed gasifier model with the indication of three main subunits of the gasification-based waste-to-energy unit and the utilised modelling parameters (TC, CC, EE, П). CC = Conversion Coefficient, HRSG = Heat Recovery and Steam Generator, LHV = Low Heating Value, $\mathrm{TC}=$ Transfer Coefficient, $\mathrm{TS}=$ Total Solids, ww = wet weight.

This configuration implies lower electricity conversion efficiencies, but larger technical reliability. It is then suitable for waste or biomass fuels that generate a syngas with a relatively large tar content, since it is able to obtain a potentially complete exploitation of the tar heating content [2]. A mild combustor [41] has been chosen for the syngas utilisation section, due to its limited 
formation of $\mathrm{NO}_{x}$, dioxins and furans (PCDD/F) and products of incomplete combustion (i.e., soot, polycyclic aromatic hydrocarbons) [42]. An Organic Rankine Cycle (ORC) has been selected for the energy generation section, assuming a conservative value of the net electrical efficiency of $17.7 \%$, evaluated for a $400 \mathrm{kWe}$ plant [38]. The APC section utilises pulverised activated carbon and hydrated lime. The first is used to adsorb $\mathrm{Hg}, \mathrm{Cd}$, low-boiling heavy metals and dioxins, and the second to neutralise $\mathrm{HCl}, \mathrm{H}_{2} \mathrm{~S}$ and $\mathrm{SO}_{x}$. Both are injected upstream of a fabric filter, which supports the acid gas removal and controls the solid particulate emissions. More details about the gasification-based unit utilised as reference can be found in [38].

\subsection{SELECTED WASTE-DERIVED FUELS}

The experimental tests were carried out with the pilot scale bubbling FBG fed with seven kinds of waste-derived fuels, together with three natural biomass fuels. The waste-derived fuels were obtained from treatments of separately collected materials [32,33]. The general description and the elemental composition of each feedstock tested in the FBG plant are shown in Table 1 and Table 2, respectively. Table 3 reports the number of experimental tests carried for each type of feedstock, together with the ranges of tested ER and the main source of data. Some experimental tests have been carried out specifically for this study with two natural biomass (WOOD1 and WOOD2) used as reference fuels, and by co-feeding Plasmix and RIL3, in order to investigate the effects of co-gasification on technical and environmental performances.

Table 1. Description of waste and biomass fuels fed into the FBG plant.

\begin{tabular}{|c|c|c|}
\hline Fuel & Feedstock & Description \\
\hline \multirow{2}{*}{ Plastics } & PE & Recycled polyethylene, derived from separate collection of MSW \\
\cline { 2 - 3 } & GS3 & $\begin{array}{c}\text { Mix of recycled polyolefinic plastics obtained from plastic packaging for } \\
\text { food and beverages by means of sorting and washing treatments }\end{array}$ \\
\hline
\end{tabular}




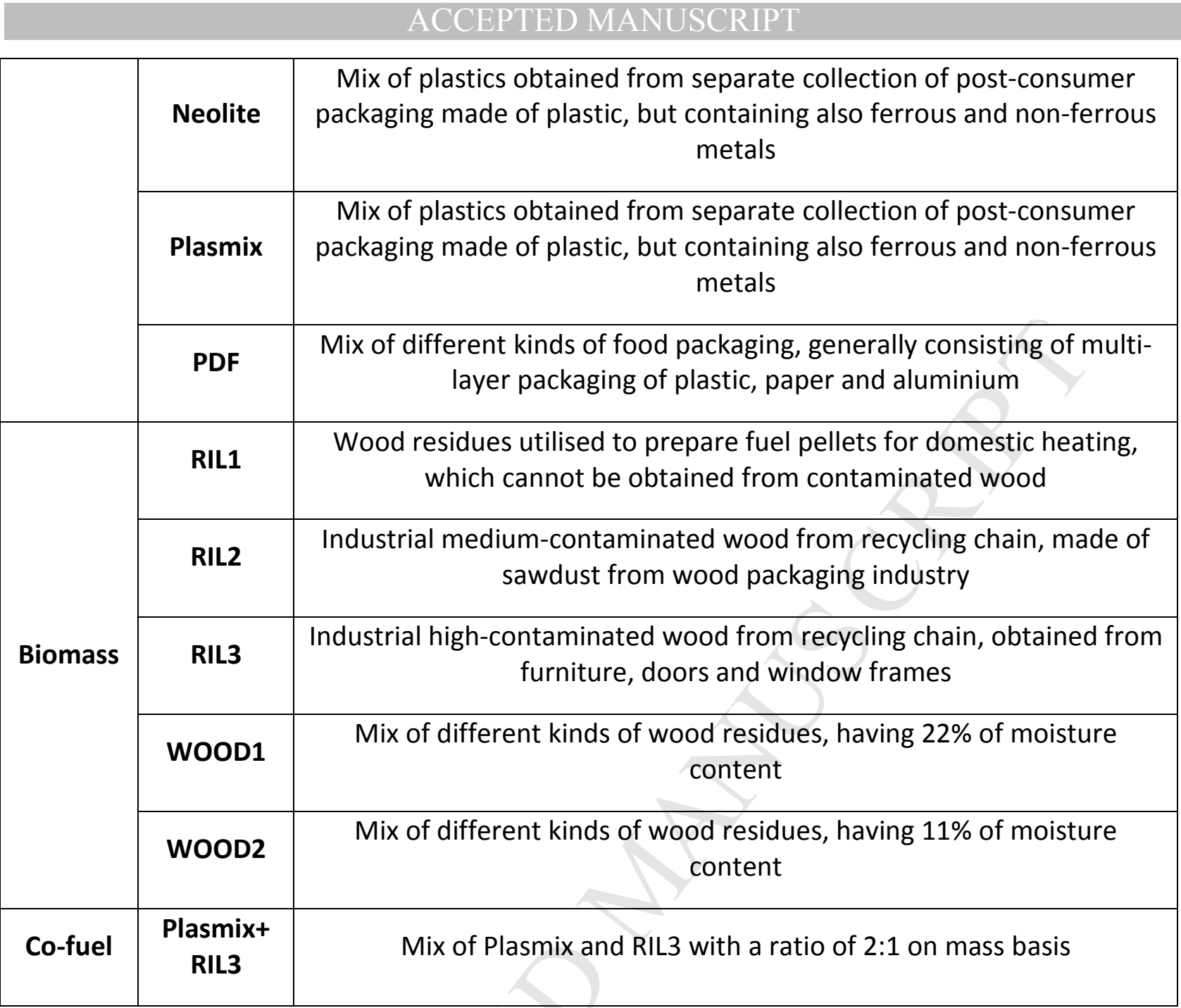

Table 2. Elemental composition of waste and biomass fuels tested in the FBG plant. TS = Total Solids, VS = Volatile Solids.

\begin{tabular}{|c|c|c|c|c|c|c|c|c|c|c|c|}
\hline \multirow{2}{*}{$\begin{array}{c}\text { Fuel } \\
\text { Feedstock }\end{array}$} & \multicolumn{5}{|c|}{ Plastics } & \multicolumn{5}{|c|}{ Biomass } & \multirow{2}{*}{$\begin{array}{c}\text { Co-fuel } \\
\text { Plasmix+ } \\
\text { RIL3 }\end{array}$} \\
\hline & PE & GS3 & Neolite & Plasmix & PDF & RIL1 & RIL2 & RIL3 & WOOD1 & WOOD2 & \\
\hline Water (\%) & 0.2 & 0.3 & 0.6 & 0.7 & 5.6 & 6.7 & 7 & 11.3 & 22 & 11 & 1.90 \\
\hline TS (\%) & 99.8 & 99.7 & 99.4 & 99.3 & 94.4 & 93.3 & 93 & 88.7 & 78 & 89 & 98.1 \\
\hline $\begin{array}{l}\text { Low Heating } \\
\text { Value } \\
\text { (MJ/kgTS) }\end{array}$ & 45.6 & 45.6 & 33.1 & 40.5 & 24.1 & 18.1 & 25.1 & 23.1 & 17.2 & 16.4 & 37.8 \\
\hline \multicolumn{12}{|c|}{ \%TS } \\
\hline VS & 99.0 & 98.7 & 93.3 & 98.1 & 93.5 & 98.9 & 98.7 & 94.9 & 99.5 & 99.0 & 97.8 \\
\hline C bio & - & - & - & - & - & 48.9 & 61.7 & 56.6 & 49.5 & 46.7 & 18.1 \\
\hline C fossil & 85.2 & 84.7 & 68.5 & 80.1 & 57.1 & - & - & - & - & - & 57.3 \\
\hline H & 13.8 & 14.0 & 10.3 & 13.2 & 8.2 & 6.0 & 7.9 & 7.9 & 5.9 & 6.2 & 12.2 \\
\hline $\mathbf{N}$ & - & - & - & 0.2 & 0.5 & 0.1 & 0.8 & 2.6 & 0.9 & 1.4 & 0.61 \\
\hline $\mathbf{S}$ & - & - & 0.1 & 0.1 & 0.1 & - & - & - & 0.1 & 0.4 & 0.1 \\
\hline
\end{tabular}




\begin{tabular}{|c|c|c|c|c|c|c|c|c|c|c|c|}
\hline \multicolumn{12}{|c|}{ ACCEPTED MANUSCRIPT } \\
\hline $\mathrm{Cl}$ & 0.002 & - & 1.019 & 0.052 & 0.282 & 0.391 & - & 0.091 & 0.052 & 0.052 & 0.06 \\
\hline 0 & - & - & 14.4 & 4.5 & 27.6 & 43.9 & 28.4 & 27.8 & 43.1 & 44.3 & 9.38 \\
\hline Ash & 1.00 & 1.30 & 6.74 & 1.91 & 6.53 & 1.07 & 1.29 & 5.07 & 0.51 & 1.01 & 2.24 \\
\hline Al & 0.02 & 0.05 & 0.10 & 0.10 & 0.26 & 0.01 & 0.01 & 0.09 & 0.03 & 0.03 & 0.097 \\
\hline As & $\begin{array}{c}1.0 \mathrm{E}- \\
05\end{array}$ & $\begin{array}{c}1.0 \mathrm{E}- \\
05\end{array}$ & $1.0 \mathrm{E}-05$ & $1.0 \mathrm{E}-05$ & $\begin{array}{c}1.0 \mathrm{E}- \\
05\end{array}$ & $\begin{array}{c}6.0 \mathrm{E}- \\
06\end{array}$ & $\begin{array}{c}4.0 \mathrm{E}- \\
05\end{array}$ & $\begin{array}{c}2.1 \mathrm{E}- \\
05\end{array}$ & - & - & $1.3 \mathrm{E}-05$ \\
\hline $\mathrm{Ba}$ & - & - & - & $1.2 \mathrm{E}-05$ & - & - & - & - & - & - & $7.8 \mathrm{E}-06$ \\
\hline $\mathbf{B i}$ & - & - & - & $1.2 \mathrm{E}-03$ & - & - & - & - & - & - & 0.0008 \\
\hline Bo & - & - & - & $1.9 \mathrm{E}-06$ & - & - & - & - & - & - & $1.3 \mathrm{E}-06$ \\
\hline $\mathrm{Ca}$ & 0.46 & 0.35 & 0.08 & 1.01 & 2.29 & 0.18 & 0.34 & 1.53 & 1.32 & 1.32 & 1.14 \\
\hline Cd & $\begin{array}{c}4.0 \mathrm{E}- \\
05\end{array}$ & $\begin{array}{c}3.6 \mathrm{E}- \\
05\end{array}$ & $2.0 \mathrm{E}-04$ & $4.8 \mathrm{E}-05$ & $\begin{array}{c}2.5 \mathrm{E}- \\
05\end{array}$ & $\begin{array}{c}6.0 \mathrm{E}- \\
06\end{array}$ & $\begin{array}{c}1.0 \mathrm{E}- \\
05\end{array}$ & $\begin{array}{c}7.6 \mathrm{E}- \\
05 \\
\end{array}$ & & - & $5.5 \mathrm{E}-05$ \\
\hline $\mathrm{Ce}$ & - & - & - & $1.4 \mathrm{E}-04$ & - & - & - & - & - & - & $9.2 \mathrm{E}-05$ \\
\hline Co & $\begin{array}{c}3.0 \mathrm{E}- \\
05\end{array}$ & $\begin{array}{c}5.1 \mathrm{E}- \\
05\end{array}$ & $1.4 \mathrm{E}-04$ & $1.1 \mathrm{E}-04$ & $\begin{array}{c}1.4 \mathrm{E}- \\
04\end{array}$ & $\begin{array}{c}1.7 \mathrm{E}- \\
05\end{array}$ & $\begin{array}{c}3.0 \mathrm{E}- \\
05\end{array}$ & $\begin{array}{c}1.0 \mathrm{E}- \\
04\end{array}$ & - & - & $1.0 \mathrm{E}-04$ \\
\hline $\mathrm{Cr}$ & $\begin{array}{c}6.8 \mathrm{E}- \\
04 \\
\end{array}$ & $\begin{array}{c}2.4 \mathrm{E}- \\
03\end{array}$ & $1.0 \mathrm{E}-02$ & $1.0 \mathrm{E}-03$ & $\begin{array}{c}6.1 \mathrm{E}- \\
04 \\
\end{array}$ & $\begin{array}{c}4.4 \mathrm{E}- \\
05 \\
\end{array}$ & $\begin{array}{c}2.0 \mathrm{E}- \\
04\end{array}$ & $\begin{array}{c}6.0 \mathrm{E}- \\
04\end{array}$ & $4.5 \mathrm{E}-03$ & $4.5 \mathrm{E}-03$ & $8.7 \mathrm{E}-04$ \\
\hline $\mathrm{Cu}$ & $\begin{array}{c}9.0 \mathrm{E}- \\
04\end{array}$ & $\begin{array}{c}1.6 \mathrm{E}- \\
03\end{array}$ & $1.3 \mathrm{E}-01$ & $1.7 \mathrm{E}-03$ & $\begin{array}{c}1.9 \mathrm{E}- \\
03\end{array}$ & $\begin{array}{c}1.0 \mathrm{E}- \\
05\end{array}$ & $\begin{array}{c}1.0 \mathrm{E}- \\
05\end{array}$ & $\begin{array}{c}3.8 \mathrm{E}- \\
04\end{array}$ & - & - & $1.28 \mathrm{E}-03$ \\
\hline $\mathrm{Fe}$ & $\begin{array}{c}2.8 \mathrm{E}- \\
03\end{array}$ & $\begin{array}{c}1.1 \mathrm{E}- \\
02\end{array}$ & $4.9 \mathrm{E}-02$ & $3.1 \mathrm{E}-02$ & $\begin{array}{c}1.4 \mathrm{E}- \\
02\end{array}$ & $\begin{array}{c}9.0 \mathrm{E}- \\
03\end{array}$ & $\begin{array}{l}4.3 \mathrm{E}- \\
02\end{array}$ & $\begin{array}{c}6.2 \mathrm{E}- \\
02\end{array}$ & $6.5 \mathrm{E}-02$ & $6.5 \mathrm{E}-02$ & $3.9 \mathrm{E}-02$ \\
\hline $\mathrm{Hg}$ & $\begin{array}{c}1.0 \mathrm{E}- \\
05\end{array}$ & $\begin{array}{c}1.0 \mathrm{E}- \\
05\end{array}$ & $1.0 \mathrm{E}-05$ & $1.0 \mathrm{E}-05$ & $\begin{array}{c}1.0 \mathrm{E}- \\
05 \\
\end{array}$ & $\begin{array}{c}1.3 \mathrm{E}- \\
05 \\
\end{array}$ & $\begin{array}{c}1.0 \mathrm{E}- \\
05\end{array}$ & $\begin{array}{c}1.0 \mathrm{E}- \\
05\end{array}$ & - & - & $9.8 \mathrm{E}-06$ \\
\hline K & 0.04 & 0.05 & 0.16 & 0.15 & 0.21 & 0.03 & 0.01 & 0.15 & 0.27 & 0.27 & 1.5E-01 \\
\hline Mg & $\begin{array}{c}8.3 \mathrm{E}- \\
02\end{array}$ & - & - & $2.5 \mathrm{E}-02$ & 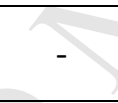 & $\begin{array}{c}1.8 \mathrm{E}- \\
02\end{array}$ & $\begin{array}{c}6.6 \mathrm{E}- \\
02\end{array}$ & $\begin{array}{c}1.3 \mathrm{E}- \\
01\end{array}$ & $2.8 \mathrm{E}-01$ & $2.8 \mathrm{E}-01$ & $5.6 \mathrm{E}-02$ \\
\hline$M n$ & $\begin{array}{c}1.0 \mathrm{E}- \\
05\end{array}$ & $\begin{array}{c}2.5 \mathrm{E}- \\
05\end{array}$ & $1.9 \mathrm{E}-03$ & $6.4 \mathrm{E}-04$ & $\begin{array}{c}7.1 \mathrm{E}- \\
04\end{array}$ & $\begin{array}{c}1.5 \mathrm{E}- \\
03\end{array}$ & $\begin{array}{c}6.3 \mathrm{E}- \\
03\end{array}$ & $\begin{array}{c}3.9 \mathrm{E}- \\
03\end{array}$ & $2.2 \mathrm{E}-02$ & $2.2 \mathrm{E}-02$ & $1.6 \mathrm{E}-03$ \\
\hline Mo & - & - & - & $2.9 \mathrm{E}-05$ & - & - & - & - & - & - & $1.94 \mathrm{E}-05$ \\
\hline $\mathrm{Na}$ & $\begin{array}{c}3.5 \mathrm{E}- \\
02\end{array}$ & $\begin{array}{c}1.7 \mathrm{E}- \\
02 \\
\end{array}$ & $7.5 \mathrm{E}-02$ & $5.3 \mathrm{E}-02$ & $\begin{array}{c}9.1 \mathrm{E}- \\
02 \\
\end{array}$ & $\begin{array}{c}1.1 \mathrm{E}- \\
02\end{array}$ & $\begin{array}{c}1.9 \mathrm{E}- \\
02\end{array}$ & $\begin{array}{c}3.5 \mathrm{E}- \\
01\end{array}$ & - & - & $1.40 \mathrm{E}-01$ \\
\hline $\mathrm{Ni}$ & $\begin{array}{c}3.0 \mathrm{E}- \\
05\end{array}$ & $\begin{array}{c}1.4 \mathrm{E}- \\
04\end{array}$ & $1.6 \mathrm{E}-02$ & $1.1 \mathrm{E}-04$ & $\begin{array}{c}6.7 \mathrm{E}- \\
04 \\
\end{array}$ & $\begin{array}{c}2.0 \mathrm{E}- \\
05\end{array}$ & $\begin{array}{c}2.0 \mathrm{E}- \\
04\end{array}$ & $\begin{array}{c}3.8 \mathrm{E}- \\
04\end{array}$ & $4.4 \mathrm{E}-03$ & $4.4 \mathrm{E}-03$ & $1.9 \mathrm{E}-04$ \\
\hline $\mathbf{P}$ & - & - & - & $2.6 \mathrm{E}-03$ & - & - & - & - & $7.4 \mathrm{E}-02$ & $7.4 \mathrm{E}-02$ & $1.8 \mathrm{E}-03$ \\
\hline $\mathrm{Pb}$ & $\begin{array}{c}3.3 \mathrm{E}- \\
03\end{array}$ & $\begin{array}{c}3.1 \mathrm{E}- \\
02\end{array}$ & 8.7E-02 & $3.4 \mathrm{E}-03$ & $\begin{array}{c}8.2 \mathrm{E}- \\
03 \\
\end{array}$ & $\begin{array}{c}1.2 \mathrm{E}- \\
04\end{array}$ & $\begin{array}{c}4.0 \mathrm{E}- \\
04\end{array}$ & $\begin{array}{c}3.5 \mathrm{E}- \\
03\end{array}$ & - & - & $3.3 \mathrm{E}-03$ \\
\hline Sb & $\begin{array}{c}1.4 \mathrm{E}- \\
04\end{array}$ & $\begin{array}{c}7.0 \mathrm{E}- \\
04\end{array}$ & $6.7 \mathrm{E}-03$ & $1.0 \mathrm{E}-05$ & $\begin{array}{c}2.0 \mathrm{E}- \\
04\end{array}$ & $\begin{array}{c}2.0 \mathrm{E}- \\
04\end{array}$ & $\begin{array}{c}6.0 \mathrm{E}- \\
05 \\
\end{array}$ & $\begin{array}{c}9.9 \mathrm{E}- \\
03\end{array}$ & - & - & $3.0 \mathrm{E}-03$ \\
\hline Si & - & - & - & $8.1 \mathrm{E}-03$ & - & - & - & - & $7.5 \mathrm{E}-01$ & $7.5 \mathrm{E}-01$ & 5.5E-03 \\
\hline Sn & $\begin{array}{c}3.2 \mathrm{E}- \\
04\end{array}$ & $\begin{array}{c}9.9 \mathrm{E}- \\
04\end{array}$ & $2.2 \mathrm{E}-03$ & $1.7 \mathrm{E}-03$ & $\begin{array}{c}7.1 \mathrm{E}- \\
04\end{array}$ & $\begin{array}{c}3.3 \mathrm{E}- \\
03\end{array}$ & $\begin{array}{c}4.1 \mathrm{E}- \\
03\end{array}$ & $\begin{array}{c}5.0 \mathrm{E}- \\
03\end{array}$ & - & - & $\begin{array}{c}0.0017854 \\
16\end{array}$ \\
\hline $\mathrm{Ti}$ & - & - & - & $1.1 \mathrm{E}-02$ & - & - & - & - & $1.3 \mathrm{E}-02$ & $1.3 \mathrm{E}-02$ & $7.2 \mathrm{E}-03$ \\
\hline $\mathrm{TI}$ & $\begin{array}{l}3.0 \mathrm{E}- \\
05\end{array}$ & $\begin{array}{c}2.5 \mathrm{E}- \\
05 \\
\end{array}$ & $2.5 \mathrm{E}-05$ & $2.5 \mathrm{E}-05$ & $\begin{array}{c}2.5 \mathrm{E}- \\
05\end{array}$ & $\begin{array}{c}1.0 \mathrm{E}- \\
06\end{array}$ & $\begin{array}{l}3.0 \mathrm{E}- \\
05\end{array}$ & $\begin{array}{c}2.5 \mathrm{E}- \\
05 \\
\end{array}$ & - & - & $2.4 \mathrm{E}-05$ \\
\hline $\mathbf{V}$ & - & $\begin{array}{c}1.5 \mathrm{E}- \\
05 \\
\end{array}$ & $1.9 \mathrm{E}-03$ & $8.0 \mathrm{E}-05$ & $\begin{array}{c}2.0 \mathrm{E}- \\
04\end{array}$ & $\begin{array}{c}1.0 \mathrm{E}- \\
05\end{array}$ & $\begin{array}{c}2.0 \mathrm{E}- \\
05\end{array}$ & $\begin{array}{c}6.1 \mathrm{E}- \\
03 \\
\end{array}$ & - & - & $1.9 \mathrm{E}-03$ \\
\hline $\mathrm{Zn}$ & - & - & - & $1.3 \mathrm{E}-03$ & - & - & - & - & $5.3 \mathrm{E}-03$ & $5.3 \mathrm{E}-03$ & $8.82 \mathrm{E}-04$ \\
\hline
\end{tabular}


Table 3. Experimental tests utilised for FBG modelling [32-37].

\begin{tabular}{|c|c|c|c|c|}
\hline Fuel & Feedstock & $\begin{array}{c}n . \text { of } \\
\text { experimental } \\
\text { tests }\end{array}$ & $\begin{array}{c}\text { Equivalence } \\
\text { Ratio }\end{array}$ & Source \\
\hline \multirow{5}{*}{ Plastics } & PE & 10 & $0.21-0.31$ & Arena et al., 2009 [32] \\
\hline & GS3 & 5 & $0.23-0.27$ & \multirow{4}{*}{$\begin{array}{c}\text { Arena et al., } 2010 \text { [33] } \\
\text { Arena et al., } 2012 \text { [35] } \\
\text { Di Gregorio and } \\
\text { Zaccariello, } 2012 \text { [36] } \\
\text { Arena and Di Gregorio, } \\
2014 \text { [37] }\end{array}$} \\
\hline & Neolite & 4 & $0.22-0.33$ & \\
\hline & Plasmix & 4 & $0.21-0.27$ & \\
\hline & PDF & 2 & $0.26-0.31$ & \\
\hline \multirow{5}{*}{ Biomass } & RIL1 & 5 & $0.20-0.30$ & \multirow{3}{*}{ Arena et al., 2010 [34] } \\
\hline & RIL2 & 3 & $0.22-0.30$ & \\
\hline & RIL3 & 3 & $0.21-0.31$ & \\
\hline & WOOD1 & 3 & $0.28-0.33$ & \multirow[t]{2}{*}{ This study } \\
\hline & WOOD2 & 6 & $0.26-0.35$ & \\
\hline Co-fuel & Plasmix+RIL3 & 1 & 0.25 & This study \\
\hline
\end{tabular}

\subsection{GENERAL ASPECTS OF THE INVENTORY MODEL}

Most of the commercial solid waste gasifiers in operation in the world are located in Asia (mainly in Japan and Korea) and utilise an autothermal gasification process $[2,3]$, which implies a sequence of endothermic and exothermic steps: initial drying, devolatilisation, partial oxidation of a fraction of volatiles and char, and gasification reactions. The proposed FBG model, based on a series of material flow analyses, defines the general relationships linking inputs and outputs of the autothermal process. The model identifies the proper waste- and process-specific parameters, reported in Figure 1 with reference to the gasification subunits of interest. These relationships quantify the main syngas characteristics, such as volumetric and mass flow rate, composition, low heating value (LHV), and the main environmental burdens, such as syngas-specific and processspecific air emissions, together with consumptions of chemicals and amount of residues sent to disposal. The FBG model starts from the feedstock feeding and the indication of its properties, 
such as composition and energy content, together with the addition of the fluidizing air stream (as quantified in the APPENDIX A).

\subsubsection{Waste-specific parameters}

Transfer Coefficient (TC) and Substance-to-Compound Conversion Coefficient (CC) are wastespecific modelling parameters utilised for the analysis of the first process subunit, which includes the gasifier and the cyclone. TCs are defined as the ratio between the mass flow rate of each element in an output stream to the mass flow rate of the same element entering into the reactor, so that they can range between 0 and 1 . The results of the experimental tests provide a set of TCs of the feedstock elements (all those of the ultimate analysis, ash, moisture, volatile solids, and total solids) for each tested fuel. TCs highlight the partitioning of the input elements (X) between the output streams of dedusted syngas ( $T C_{X}$ to syngas $)$ and that of ashes discharged from the cyclone and the bed bottom ( $\mathrm{TC}_{\mathrm{x}}$ to ashes).

The carbon and hydrogen transfer coefficients are coupled with the related substance-tocompound Conversion Coefficients (CCs), which indicate the amount of $\mathrm{C}$ and $\mathrm{H}$ transferred into specific syngas compounds (i.e., $\mathrm{CH}_{4}, \mathrm{CO}_{2}, \mathrm{CO}$, tar, $\mathrm{H}_{2}, \mathrm{H}_{2} \mathrm{O}$ and $\mathrm{C}_{n} \mathrm{H}_{m}$ with $\mathrm{n}$ equals to 2 or 3 and $\mathrm{m}$ equals to 2, 4 or 6). Carbon-to-compound CCs have been obtained from experimental results by dividing the carbon mass flow rate in each syngas compound with the total carbon flow rate in the syngas. The same procedure has been applied for hydrogen, by coupling the experimental results with the atomic balances, and taking into account the amount of hydrogen present in the compounds already quantified by carbon-to-compounds CCs. The model then provides the main syngas characteristics, such as mass and volumetric flow rate, composition, and LHV. In particular, the volumetric flow rates of each compound in dry syngas, as well as mass flow rates of tars can be determined by the following two relationships. 
Compound $i\left[\mathrm{~m}_{\mathrm{N}}^{3} / \mathrm{h}\right]=\mathrm{kg} \_\mathrm{X} * \mathrm{TC}_{\mathrm{X}}$ to syngas $* \mathrm{CC}_{\mathrm{X}}$ to $i *$ Volume_gas $/\left(\mathrm{MW} \_\mathrm{X}^{*} \mathrm{n}\right)$

Where:

- $\quad i$ indicates $\mathrm{CH}_{4}, \mathrm{CO}_{2}, \mathrm{CO}$, tar, $\mathrm{H}_{2}, \mathrm{H}_{2} \mathrm{O}, \mathrm{C}_{\mathrm{n}} \mathrm{H}_{\mathrm{m}}, \mathrm{N}_{2}$;

- $\quad k g \_X$ indicates the input of each element $(\mathrm{C}, \mathrm{H}$, and $\mathrm{N})$ expressed as $\mathrm{kg} / \mathrm{h}$;

- MW_X indicates the atomic weight of each element ( $C, H$, and $N$ ) expressed as $\mathrm{kg} / \mathrm{kmol}$;

- Volume_gas is the molar volume of the ideal gases, equals to $22.4 \mathrm{~m}^{3} \mathrm{~N} / \mathrm{kmol}$.

- TC and CC for $\mathrm{H}, \mathrm{C}$ and $\mathrm{N}$ are the coefficients for each kind of feedstock obtained from the experiments.

- $\mathrm{n}$ is the number of atoms of the element $\mathrm{X}$ in the compound $i$. It is set equal to 2 for $\mathrm{C}_{\mathrm{n}} \mathrm{H}_{\mathrm{m}}$, which is an average value, based on the results of experimental tests.

$\operatorname{Tar}_{\text {syngas }}[\mathrm{kg} / \mathrm{h}]=\mathrm{kg} \_\mathrm{C} * \mathrm{TC}_{\mathrm{C} \text { to syngas }} * \mathrm{CC}_{\mathrm{C} \text { to Tar }} / \% \mathrm{C}_{\mathrm{tar}}$

Where:

- $\quad \mathrm{kg} \_\mathrm{C}$ is the input expressed as $\mathrm{kg} / \mathrm{h}$ of $\mathrm{C}$;

- TC and CC for C are the coefficients for each kind of feedstock obtained from the experiments.

- $\%_{m} C_{t a r}$ is the mass fraction of carbon in tar compounds and it is assumed to be equal to 0.87 , which is an average value based on the experimental tests.

\subsubsection{Process-specific parameters}

With reference to the process scheme of Figure 1, several process-modelling parameters have been defined for the syngas combustor, the HRSG unit and the APC system. The identification of proper values for these process-specific parameters has been based on operational data for all the analysed fuels. Table 4 lists these parameters, the utilised values and the related data sources.

Table 4. Parameters utilised for FBG modelling, for each process stage and valid for all types of waste and biomass fuels (process-specific parameters).

\begin{tabular}{|rccc|}
\hline Process parameters & Amount & Short Symbol & Source \\
\hline Syngas combustor and HRSG section & & & \\
\hline $\begin{array}{r}\text { Net electrical efficiency of the Organic } \\
\text { Rankine Cycle turbine, } \%\end{array}$ & 17.7 & EE & Arena et al., 2015 [38] \\
\hline APC system & & & \\
\hline Activated carbon consumption, $\mathrm{kg} / \mathrm{t}_{\text {feedstock }}$ & 0.5 & - & Ardolino et al., 2017 [29] \\
\hline
\end{tabular}




\begin{tabular}{|c|c|c|c|}
\hline Hydrated lime consumption, $\mathrm{kg} / \mathrm{t}_{\text {feedstock }}$ & 6.5 & - & Ardolino et al., 2017 [29] \\
\hline $\begin{array}{r}\text { Removal efficiency obtained by the APC } \\
\text { system (fabric filter + activated carbon), \% }\end{array}$ & 99 & $\eta_{\mathrm{APC}}$ & Ardolino et al., 2017 [29] \\
\hline $\begin{array}{r}\mathrm{HCl} \text { removal efficiency by means of } \\
\text { hydrated lime, \% }\end{array}$ & 99 & $\eta_{\mathrm{HCl}}$ & Ardolino et al., 2017 [29] \\
\hline $\begin{array}{r}\mathrm{SO}_{\mathrm{x}} \text { removal efficiency by means of } \\
\text { hydrated lime, } \%\end{array}$ & 95 & $\eta_{\mathrm{SO} 2}$ & Ardolino et al., 2017 [29] \\
\hline $\mathrm{NH}_{3}$ emissions, $\mathrm{mg} / \mathrm{kg}_{\text {syngas }}$ & 0.038 & - & Ardolino et al., 2017 [29] \\
\hline $\mathrm{NO}_{x}$ emissions, $\mathrm{mg} / \mathrm{kg}_{\text {syngas }}$ & 73 & - & $\begin{array}{l}\text { Ardolino et al., } 2017 \text { [29] } \\
\text { Cavaliere and de Joannon } 2004 \\
\text { [41] }\end{array}$ \\
\hline PCDD/F emissions, $\mathrm{ng} / \mathrm{kg}_{\text {syngas }}$ & 0.0074 & - & Ardolino et al., 2017 [29] \\
\hline
\end{tabular}

\subsubsection{Life cycle inventory model}

The main inputs and outputs provided by the inventory model, and based on the identified wasteand process-specific parameters, are: air emissions, electricity recovery, residues to be disposed, and material consumptions. Air emissions can be quantified in terms of syngas- and processspecific emissions. Syngas-specific emissions into the atmosphere are strictly related to the syngas composition, and include fossil carbon dioxide, sulphur dioxide, hydrogen chloride, heavy metals and particulate matter. Some of these emissions can be quantified by means of the following relationships.

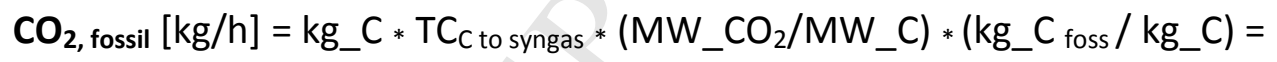

$$
\begin{aligned}
& =\left[\left(\mathrm{CO}_{\text {syngas }}+\mathrm{CO}_{2 \text { syngas }}+\mathrm{CH}_{4 \text { syngas }}+2 \mathrm{C}_{\mathrm{n}} \mathrm{H}_{\text {m syngas }}+6 \mathrm{BTX} \text { syngas }\right) /(\text { Volume_gas }) *\left(\mathrm{MW}_{-} \mathrm{CO}_{2}\right)\right. \\
& \left.+\left(\operatorname{tar}_{\text {syngas }} * \% \mathrm{~m}_{\mathrm{m}} \mathrm{C}_{\mathrm{tar}} / \mathrm{MW} \_\mathrm{C} * \mathrm{MW} \_\mathrm{CO}_{2}\right)\right] * \% \mathrm{C}_{\text {foss }} \\
& \mathrm{SO}_{2}[\mathrm{~kg} / \mathrm{h}]=\left[\mathrm{kg} \_\mathrm{S} * \mathrm{TC} \mathrm{S}_{\text {to syngas }} *\left(1-\eta_{\mathrm{SO}}\right)\right] * \mathrm{MW}_{-} \mathrm{SO}_{2} / \mathrm{MW} \_\mathrm{S} \\
& \mathrm{HCl}[\mathrm{kg} / \mathrm{h}]=\left[\mathrm{kg} \_\mathrm{Cl} * \mathrm{TC} \mathrm{Cl} \text { to syngas } *\left(1-\eta_{\mathrm{HCl}}\right)\right] * \mathrm{MW} \_\mathrm{HCl} / \mathrm{MW} \_\mathrm{Cl}
\end{aligned}
$$

Where:

- $\quad$ kg_C, kg_C foss, $\mathrm{kg}$ _S , and kg_Cl are the FBG inputs, expressed as kg/h of total C, fossil C, S, and $\mathrm{Cl}$, respectively.

- TC are the coefficients for each kind of feedstock obtained from the experiments. 
- $\mathrm{MW} \_\mathrm{CO}_{2}, \mathrm{MW} \_\mathrm{C}, \mathrm{MW} \mathrm{SO}_{2}, \mathrm{MW} \_\mathrm{S}, \mathrm{MW} \_\mathrm{HCl}$, and $\mathrm{MW} \_\mathrm{Cl}$ are the molecular weights, expressed as $\mathrm{kg} / \mathrm{kmol}$ of $\mathrm{CO}_{2}, \mathrm{C}, \mathrm{SO}_{2}, \mathrm{~S}, \mathrm{HCl}$, and $\mathrm{Cl}$, respectively.

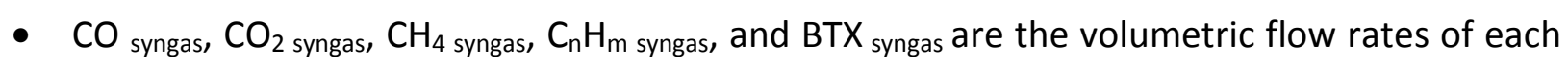
compound in the syngas, quantified by the relationships 1 , expressed as $m^{3}{ }_{N} / h$.

- $\operatorname{tar}_{\text {syngas }}$ is the mass flow rate of tar in syngas, quantified by the relationship 2 , expressed as $\mathrm{kg} / \mathrm{h}$.

- $\eta_{\mathrm{sO} 2}$ and $\eta_{\mathrm{HCl}}$ are the pollutants removal efficiencies, reported in Table 4.

- Volume_gas is the molar volume of the ideal gases, equals to $22.4 \mathrm{~m}^{3} \mathrm{~N} / \mathrm{kmol}$.

- $\quad{ }_{\mathrm{m}} \mathrm{C}_{\mathrm{tar}}$ is the mass fraction of carbon in tar compounds and it is assumed to be equal to 0.87 , which is an average value based on the experimental tests.

- $\% \mathrm{C}_{\text {foss }}$ is the ratio of mass flow rate of fossil carbon entering into reactor and that of total carbon.

Heavy metals and particulate matter emissions strictly depends on the fate of the ash forming matter. The latter, contained in the fuel as discrete particles or inclusions of the combustible matrix, can be converted into solid, liquid and gaseous compounds, and finally leaves the system as gas effluents, bottom ashes or fly ashes. Conversion of ash-forming material depends on many factors, such as temperature, surrounding gas atmosphere (oxidising or reducing), pressure, fuel particle size distribution, residence time. The form of occurrence of the ash-forming compounds in the fuel is another important factor $[43,44]$. Upon oxidising atmosphere, discrete mineral particles are quickly isolated at high temperatures, and then condensed during the cooling stage after leaving the furnace. Included minerals become more concentrated in the fuel matrix as the connecting hydrocarbon is consumed. Metal oxides can be reduced by carbon and then partially undergo oxidation, clustering and coalescence, forming a significant part of the particulate to be collected by the dust control system. The gasification environment reduces metal oxides to elemental metals, which have a lower boiling point, in a reacting atmosphere without any reoxidation and clustering $[45,46]$. The quantification of the generated solid residues from the 
process (that is, the ashes from bed bottom and cyclone, and the fly ashes from APC section) together with air emissions of heavy metals and particulates have to take into account these phenomena. A reasonable estimation of these outputs can be done by means of the following relationships within the APC subunit:

FBG Ashes $[\mathrm{kg} / \mathrm{h}]=\mathrm{kg} \_\mathrm{X} * \mathrm{TC} \mathrm{X}$ to ashes

APC residues $[\mathrm{kg} / \mathrm{h}]=\left(\mathrm{kg} \_\right.$Ashes $\left.* \mathrm{TC}_{\text {ashes to syngas }} * \eta_{\text {APC }}\right)+\mathrm{kg} \_$Spent chemicals

Heavy metal $\boldsymbol{y}[\mathrm{kg} / \mathrm{h}]=\mathrm{kg} \_$Heavy_metal_$\_y * T C_{\text {metal } y \text { to syngas }} *\left(1-\eta_{\text {APC }}\right)$

$\mathbf{P M 2 . 5}[\mathrm{kg} / \mathrm{h}]=\mathrm{kg} \_$Ashes $* \mathrm{TC}_{\text {ashes to syngas }} *\left(1-\eta_{\mathrm{APC}}\right)$

Where:

- $\quad$ kg_Ashes, kg_X and kg_Heavy_metal_y are the FBG input, expressed as kg/h;

- $T C_{X}$ to ashes are the specific quantified coefficients for each element entering into FBG with the feedstock (that is inorganic elements but also $C$ and hydrogen) transferred to the FBG ashes.

- $\mathrm{TC}_{\text {metal }} y$ to syngas is the specific quantified coefficient for each metal entering into FBG with the feedstock and transferred to the syngas as elemental metal.

- $\quad \mathrm{TC}_{\text {ashes to syngas }}$ is the specific quantified coefficient for ashes entering into FBG and escaping the reactor and the cyclone as particles in the syngas.

- $\eta_{\text {APC }}$ is the removal efficiency obtained by the APC system (fabric filter + activated carbon) reported in table 4.

- kg_Spent chemicals are chemicals utilised in the APC system, expressed as kg/h.

In particular, the value of $\mathrm{TC}_{\text {ashes in syngas }}$ is affected by the design of the specific cyclone as well as by density and, above all, size distribution of particles generated during the FBG process. The latter parameters are in turn related to the above cited fate of the ash forming matter contained in the fuel [44] and the comminution phenomena (attrition, fragmentation, and percolation) occurring in the reactor $[2,46]$. A reasonable estimation of this value can be obtained based on 
data coming from the complete series of experimental activity with the pilot scale gasifier. However, the amount of ashes escaping the cyclone as particles in the syngas is generally very low, or negligible, when the gasifier is fed with plastic waste [2,33]. Process-specific air emissions include $\mathrm{NH}_{3}, \mathrm{NOx}$, and PCDD/F. They are quantified on the basis of the amount of the produced syngas, as indicated in Table 4.

The specific electricity recovery has been calculated considering the chemical energy transferred to the syngas and the net electrical efficiency of syngas utilisation section, as showed by the following two relations, one for the recovered electricity and the second one LHV of the dry syngas.

Recovered electricity $\left[\mathrm{kWh} / \mathrm{kg}_{\text {feedstock }}\right]=\mathrm{LHV}$ Dry syngas $*$ Dry syngas specific yield $* \mathrm{EE}$

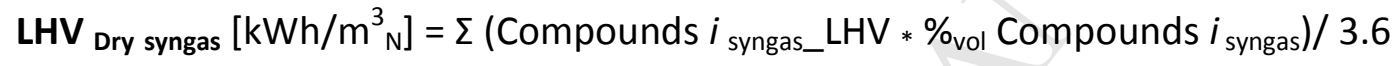

Where:

- Dry syngas specific yield is the sum of syngas compounds (i.e. $\mathrm{CO}, \mathrm{CH}_{4}, \mathrm{C}_{n} \mathrm{H}_{\mathrm{m}}, \mathrm{H}_{2}$, tar, BTX, and $\mathrm{N}_{2}$ ), expressed as $\mathrm{m}^{3} \mathrm{~N} / \mathrm{kg}$ feedstock.

- $\quad E E$ is the net electrical efficiency reported in Table 4.

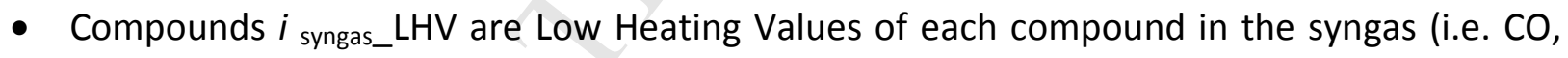
$\mathrm{CH}_{4}, \mathrm{C}_{\mathrm{n}} \mathrm{H}_{\mathrm{m}}, \mathrm{H}_{2}$, tar, BTX, and $\mathrm{N}_{2}$ ), expressed as $\mathrm{MJ} / \mathrm{m}^{3}$.

- $\%_{\text {vol }}$ Compounds $i_{\text {syngas }}$ are the volumetric fractions of each compound in the syngas (i.e. $\mathrm{CO}, \mathrm{CH}_{4}, \mathrm{C}_{\mathrm{n}} \mathrm{H}_{\mathrm{m}}, \mathrm{H}_{2}$, tar, BTX, and $\mathrm{N}_{2}$ ).

- 3.6 is the conversion factor from MJ to kWh.

\subsection{LCA CASE STUDY}

\subsubsection{Goal and scope definition}

The described FBG model has been used to develop an attributional and standardised LCA case study [47], carried out with the EASETECH software package. The intended application is investigating and quantifying the environmental performances of a FBG process, fed with different 
waste and biomass fuels. The functional unit is "the production of $1 \mathrm{kWh}$ of electricity from the syngas combustion". The system boundaries (Figure 2) include all the activities from the delivery of the feedstock at the FBG entry gate until to the management of all process residues. They can be schematised in a foreground system (i.e. the one analysed) and a background system (i.e. that interacting with the investigated system in order to provide the necessary materials and energy).

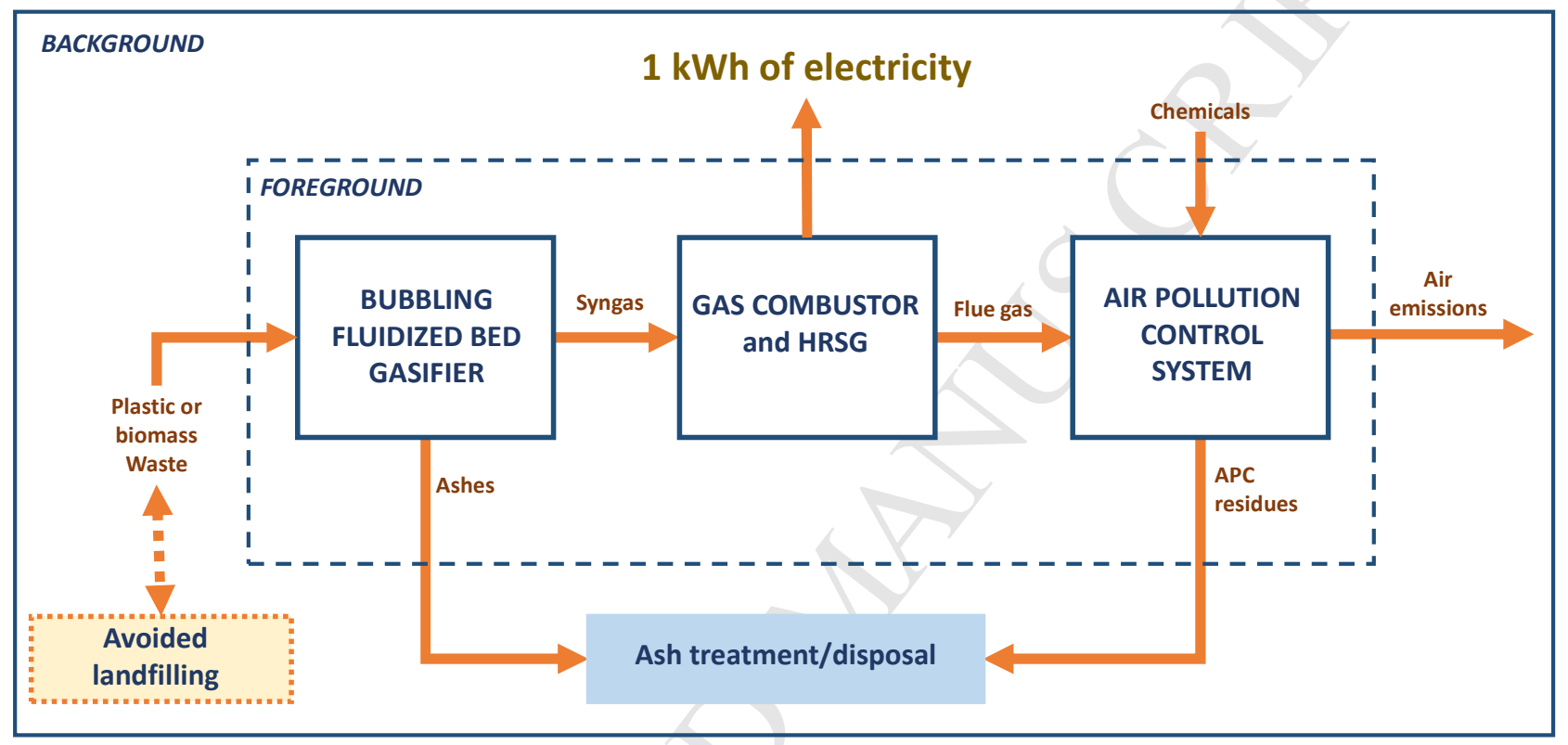

Figure 2. System boundaries of the analysed fluidized bed gasifier, together with the indication of the foreground and background systems. APC = Air Pollution Control, HRSG = Heat Recovery and Steam Generator.

Data utilised for the foreground system derive from on-field experimental activities, and then are of high quality. Data for background system are provided by the ELCD 3.1 databank. The multifunctionality's allocation issues of the analysed system (i.e. the production of electricity and the waste safe disposal) have been approached with the system expansion methodology [48], by identifying which waste treatments are avoided when waste is instead gasified in the FBG. Life cycle environmental impacts have been assessed by means of the ILCD 2011 methodology, developed by Joint Research Centre of the European Commission, and which includes 16 midpoint 
categories related to climate change, human health, eco-terrestrial toxicity and resource consumptions [49].

\section{RESULTS AND DISCUSSION}

\subsection{Determination of waste specific parameters}

Carbon transfer coefficients into the syngas ( $\mathrm{TC}_{\mathrm{C}}$ to syngas) for each of the fuels under analysis coincide with the related carbon conversion efficiency (CCE), defined as the flow rate of C converted to gaseous products with respect to that fed to the reactor. The average values of these $\mathrm{TC}_{\mathrm{C} \text { to syngas }}$ range from 0.84 to 0.98 for the selected waste fuels, as shown in Figure 3 , together with the standard deviation estimated by taking into account the different values of ER.

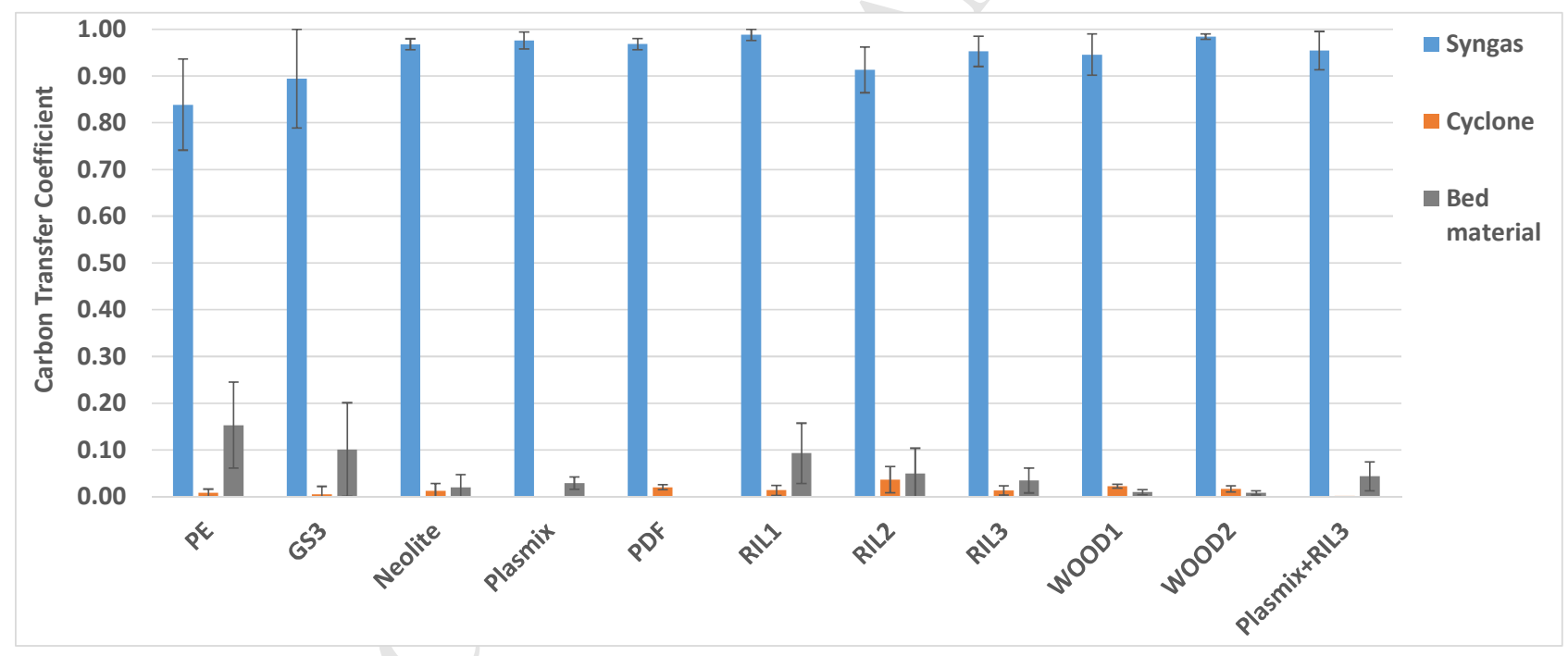

Figure 3. Carbon transfer coefficients into syngas, cyclone and bed material for the selected fuels. Standard deviation (shown as bars) indicate the variations of TCs with reference to different values of ER.

Hydrogen transfer coefficients into the syngas ( $\mathrm{TC}_{\mathrm{H}}$ to syngas) are generally higher than 0.99 , while TCs into the syngas for oxygen, nitrogen, sulphur and chlorine are set equal to 1 , then assuming that they are totally transferred into the produced syngas. With reference to the CCs, feedstock materials show different gasification behaviours (Figure 4). 


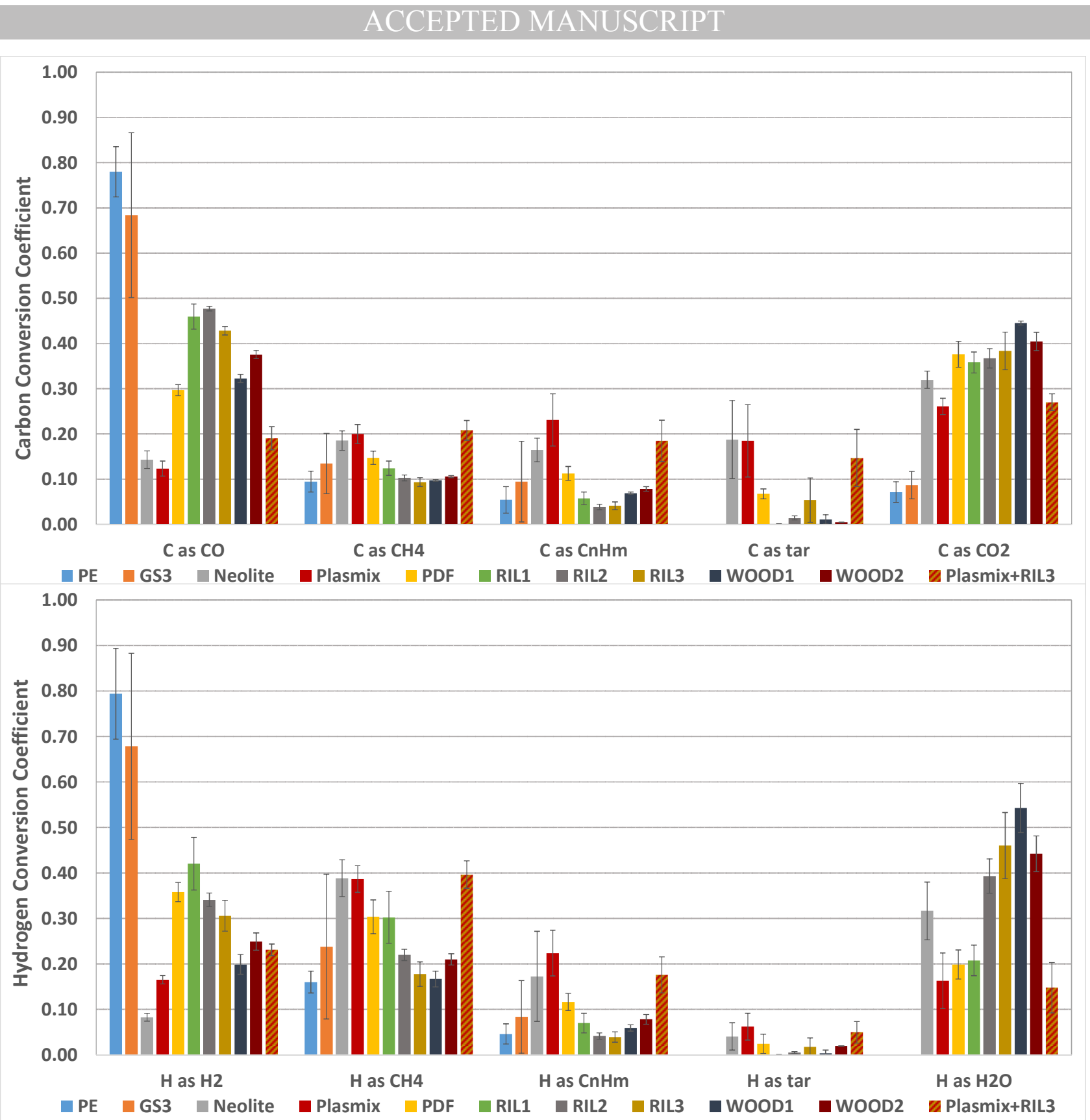

Figure 4. Carbon-to-compounds (up) and Hydrogen-to-compounds (bottom) conversion coefficients for the selected feedstock materials. Standard deviation (shown as bars) indicate the variations of CCS with reference to different values of ER.

In particular, carbon contained in polyolefin wastes - the quasi-pure plastic streams, named PE and GS3 - is converted mainly into CO. For these wastes, the carbon conversion into tar is very low or substantially zero, due to the huge catalytic effect of olivine particles utilised as bed materials, which greatly improves the extension of tar cracking (dehydrogenation) and carbonization reactions [50]. On the contrary, this effect is only partially present during the gasification of other 
plastic fuels derived from the separate collection of MSW or industrial biomass waste, due to the inhibiting effects of metal impurities [33,37]. This catalytic effect is also evident in the high C content inside the bed (Figure 3), which is a result of the catalysed carbonization reaction [50]. In particular, the larger standard deviation appearing in Figure 3 for PE and GS3 is likely related to the uncertainty in the amount of $\mathrm{C}$ on the bed particles, which is affected by the quality and quantity of the bed sampling. Carbon and hydrogen entering with Plasmix, Neolite, and PDF are for larger extents converted into $\mathrm{CO}_{2}, \mathrm{CH}_{4}, \mathrm{C}_{n} \mathrm{H}_{m}$ and tar, with lower generation of $\mathrm{CO}$. Among the tested biomass fuels, the differences about carbon and hydrogen conversion coefficients are less evident, even though carbon entering with RIL3 shows the higher conversion into tar, because of the presence of glues and other additives in the biomass waste. As expected, the cogasification of Plasmix and RIL3 contributes to attenuate the disadvantages of the co-fuels, mainly in terms of tar and heavier hydrocarbons generation. These results suggest that the olivine bed particles work as an efficient tar removal catalyst during gasification of PE and GS3, and, even though to a lesser extent, of uncontaminated biomass. This positive effect reduces during operation with other fuels, which derived from biomass or plastics containing impurities. The differences, discussed in detail in $[32,33]$ are crucial in the FBG modelling for life cycle assessment, since they largely affect the quantification of the main environmental burdens.

TCs of inorganics found in the fines collected at the cyclone have been quantified for PE, PDF, Plasmix, RIL1, RIL2, and RIL3 (Table 5): some elements showed an enrichment phenomenon, which leads to a mass flow rate in output higher than that in input. This phenomenon can be partially affected by the possible uncertainties in the metal content of the collected fines. Anyway, it is particularly interesting for iron, since part of that present on the external surface of olivine particles (and responsible of the catalytic activity for tar cracking) escapes the reactor due to the mechanical attrition between bed particles [50]. Based on these observations and taking into 


\section{ACCEPTED MANUSCRIPT}

account typical cyclone efficiencies $[46,51]$, TC for the total mass flow rate of ash entering with feedstock and transferred to the fines collected from cyclone has been conservatively set equal to 0.90. Accordingly, TC of ashes transferred to the syngas as particle has been set equal to 0.10 .

Table 5. TCs of inorganic in the fines collected at the cyclone, for some of tested waste and biomass fuels [32-34].

\begin{tabular}{|c|c|c|c|c|c|c|c|c|}
\hline & \multicolumn{7}{|c|}{ TCs of inorganics in ashes from cyclone } & \multirow[t]{2}{*}{ as } \\
\hline & PE & Plasmix & PDF & RIL1 & RIL2 & RIL3 & $\begin{array}{c}\text { Plasmix+ } \\
\text { RIL3 }\end{array}$ & \\
\hline As & 0.28 & 0.00 & 0.00 & 1.10 & 0.01 & 0.10 & 0.01 & As \\
\hline Al & 0.89 & 0.01 & 1.07 & 0.91 & 1.00 & 0.37 & 0.04 & $\mathrm{Al}_{2} \mathrm{O}_{3}$ \\
\hline $\mathbf{S b}$ & 0.77 & 0.46 & 0.41 & 0.03 & 0.85 & 0.03 & 0.02 & $S b$ \\
\hline $\mathrm{Cd}$ & 0.70 & 0.01 & 0.20 & 0.40 & 0.73 & 0.13 & 0.02 & $C d$ \\
\hline $\mathrm{Ca}$ & 0.23 & 0.00 & 0.00 & 0.12 & 0.30 & 0.22 & 0.02 & $\mathrm{CaO}$ \\
\hline Co & 21.5 & 0.01 & 1.63 & 6.86 & 2.97 & 0.22 & 0.03 & Co \\
\hline $\mathrm{Cr}$ & 5.70 & 0.01 & 1.18 & 3.79 & 2.61 & 0.34 & 0.05 & $\mathrm{Cr}$ \\
\hline Fe & 189 & 0.04 & 0.01 & 8.80 & 3.38 & 0.68 & 0.08 & $\mathrm{Fe}_{2} \mathrm{O}_{3}$ \\
\hline $\mathrm{Mg}$ & 0.02 & 0.04 & 0.00 & 5.97 & 1.79 & 0.31 & 0.05 & $M g O$ \\
\hline$M n$ & 527 & 0.02 & 1.57 & 0.39 & 0.29 & 0.21 & 0.04 & $\mathrm{MnO}$ \\
\hline $\mathrm{Hg}$ & 0.28 & 0.00 & 0.06 & 0.42 & 0.03 & 0.00 & 0.00 & $H g$ \\
\hline $\mathbf{N i}$ & 599 & 0.76 & 3.38 & 35.00 & 10.4 & 0.82 & 0.25 & $\mathrm{Ni}$ \\
\hline $\mathrm{Pb}$ & 0.26 & 0.01 & 0.06 & 1.30 & 1.35 & 0.69 & 0.06 & $P b$ \\
\hline$K$ & 0.02 & 0.00 & 0.06 & 0.22 & 0.70 & 0.12 & 0.01 & $\mathrm{~K}_{2} \mathrm{O}$ \\
\hline $\mathrm{Cu}$ & 1.25 & 0.01 & 0.83 & 16.49 & 41.5 & 0.77 & 0.11 & $\mathrm{Cu}$ \\
\hline $\mathrm{Na}$ & 0.12 & 0.00 & 0.34 & 0.05 & 0.84 & 0.02 & 0.01 & $\mathrm{Na}_{2} \mathrm{O}$ \\
\hline Sn & 8.76 & 0.00 & 1.96 & 0.03 & 0.00 & 0.07 & 0.02 & Sn \\
\hline $\mathrm{TI}$ & 0.11 & 0.00 & 0.06 & 0.01 & 0.03 & 0.00 & 0.00 & $T I$ \\
\hline $\mathbf{v}$ & 17.9 & 0.01 & 2.70 & 1.93 & 1.19 & 0.01 & 0.00 & $v$ \\
\hline $\mathrm{Cl}$ & 0.00 & 0.00 & 0.00 & 0.00 & 0.00 & 0.00 & 0.00 & $\mathrm{Cl}$ \\
\hline
\end{tabular}


TCs of inorganics in ashes are utilised also for the quantification of TCs for metals (As, Cd, Cr, Cu, $\mathrm{Fe}, \mathrm{Hg}, \mathrm{Pb}$, and $\mathrm{Sb}$ ) entering into the $\mathrm{FBG}$ with the feedstock and transferred into the syngas as elemental metals (Figure 5), assuming negligible their stocks in the reactor [35]. Different values of TCs for metals are mainly related to the composition of feedstock, conversion of ash-forming material, and catalytic activity for tar cracking [43]. An average value of 0.45 for TC of $\mathrm{Zn}$ into syngas has been assumed for all the fuels, based on data reported by Arena and Di Gregorio [37].

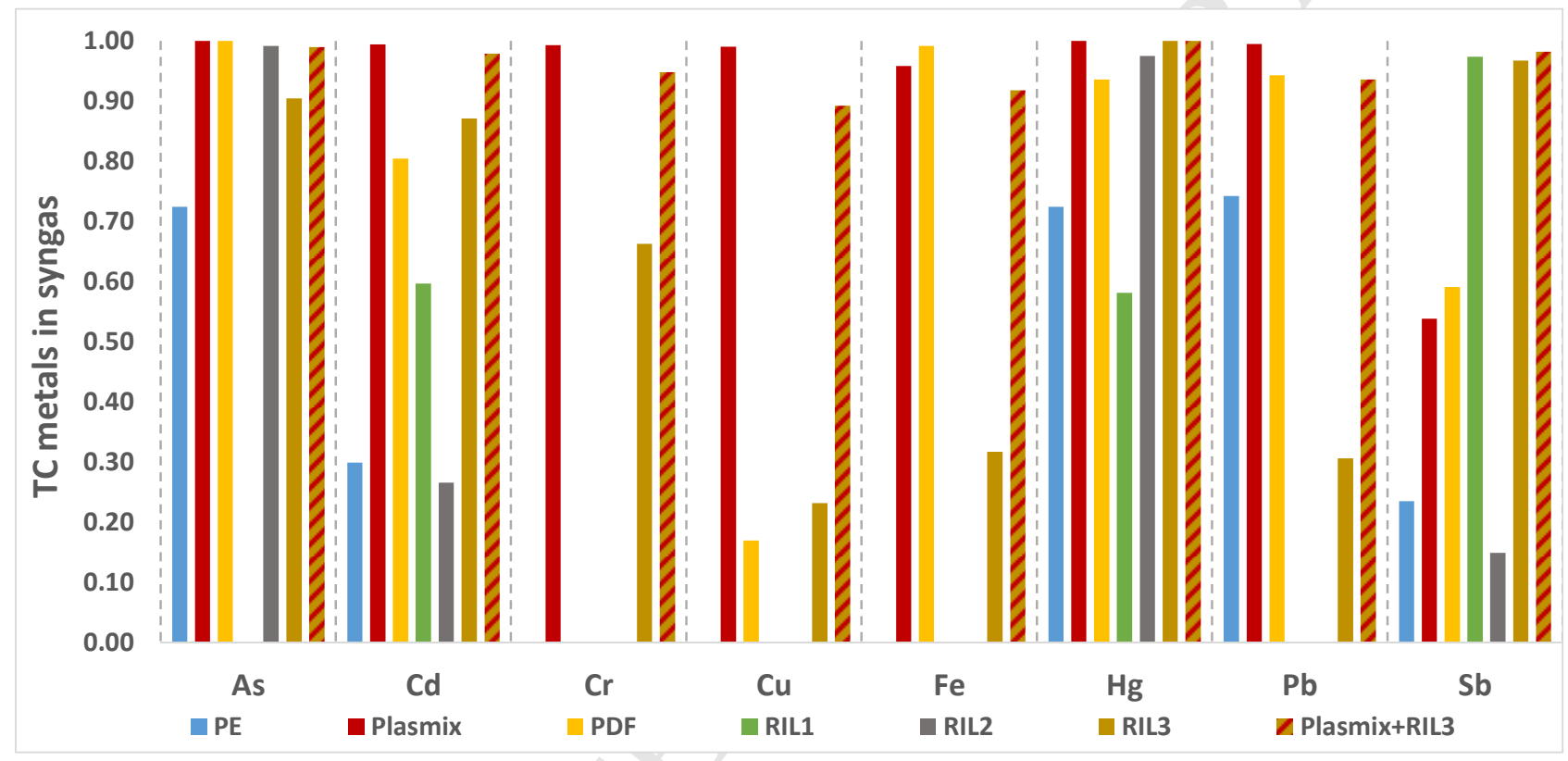

Figure 5. Estimated transfer coefficients (TCs) for metals ( $\mathrm{As}, \mathrm{Cd}, \mathrm{Cr}, \mathrm{Cu}, \mathrm{Fe}, \mathrm{Hg}, \mathrm{Pb}$, and $\mathrm{Sb}$ ) entering into fluidized bed gasifier with the feedstock and transferred to the syngas as elemental metal.

The FBG model has been utilised for the quantification of two process performances: dry syngas yield and cold gas efficiency (CGE). The first is the sum of the volumetric flow rates of the dry syngas compounds. The second is the ratio between the chemical energy of the produced syngas and that of the feedstock fed to the reactor. 

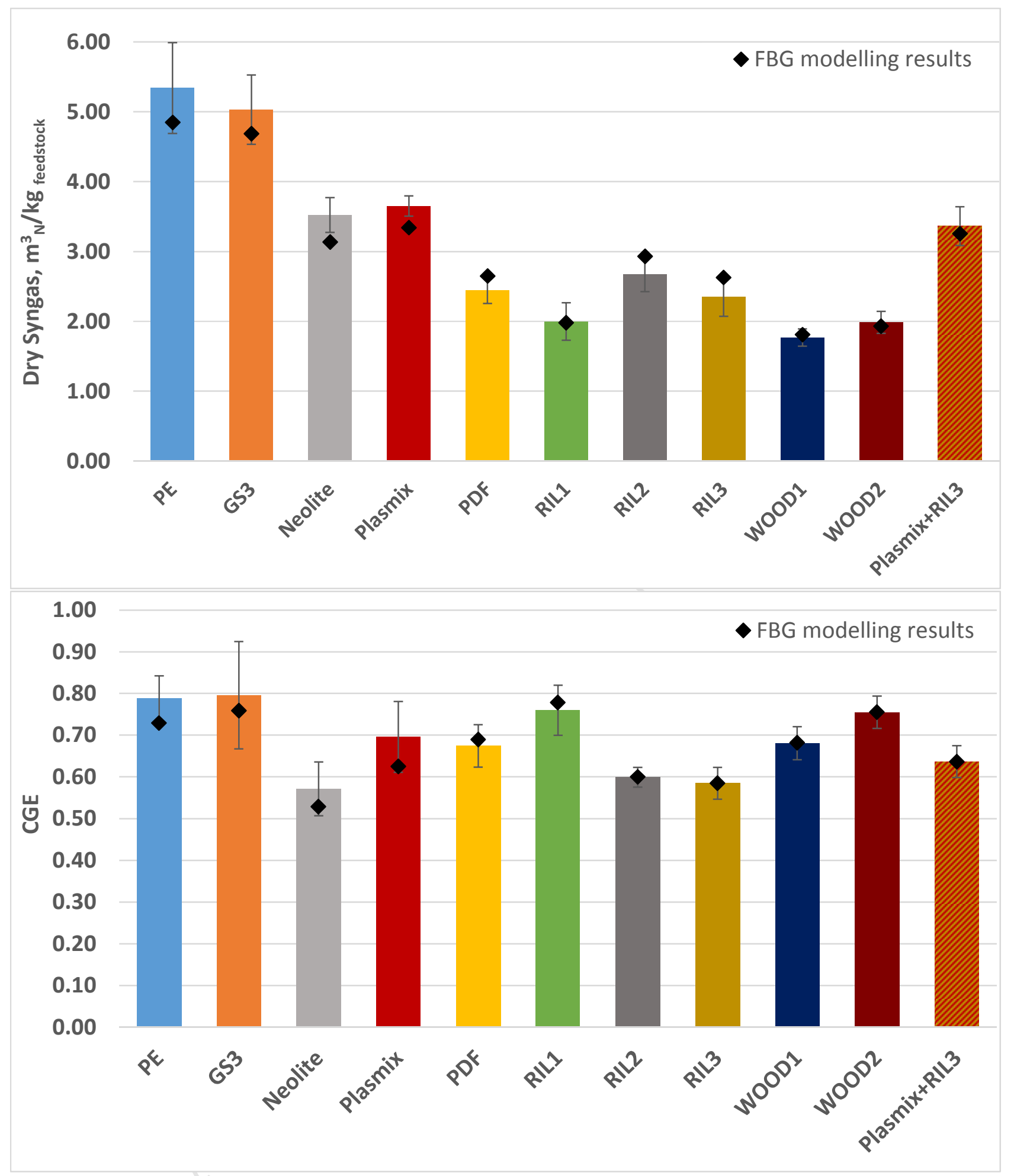

Figure 6. Comparison between experimental and modelling results, in terms of dry syngas yield (up) and Cold Gas Efficiency (bottom).

Results obtained from the FBG model, reported in Figure 6 and Figure 7, appear generally in fair agreement with those evaluated during experimental activity. The average error is, in particular, 3.5\% for CGE and $6.1 \%$ for dry syngas yields. This rather good agreement was only partially 
expected, considering that experimental values were obtained for different values of equivalence ratio, fluidizing velocity and air preheating temperature, while the model assumes average values for all these parameters. A sensitivity analysis has been developed to investigate more on their effect.

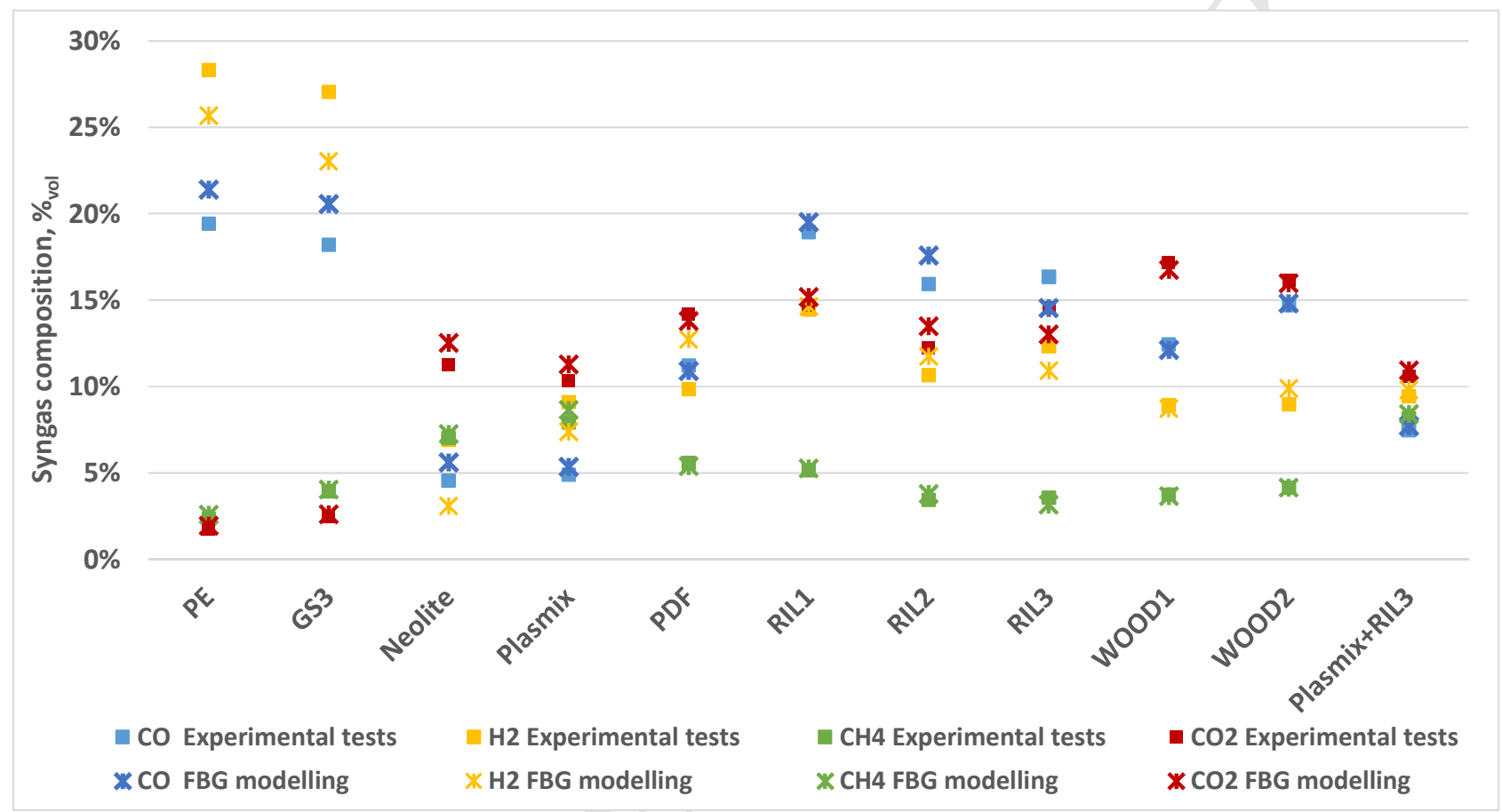

Figure 7. Comparison between experimental and modelling results, in terms of volumetric concentration of the main syngas compounds.

\subsection{LCI and LCIA RESULTS}

Based on the standard procedures and the methodology described above, the FBG model implemented in EASETECH defines a life cycle inventory for the gasification process of the selected waste-derived fuels. Table 6 shows the LCl table, which also contains the feedstock amount required to obtain the production of $1 \mathrm{kWh}$ of electricity. The direct emissions into the atmosphere for all the waste and biomass under analysis have been quantified by assuming that the TCs of metals (Figure 5) defined for PE can be utilised also for GS3, those of Plasmix also for Neolite, and those of RIL1 also for WOOD1 and WOOD2, based on their similar chemical 
compositions and gasification behaviours. Burdens related to landfilling of plastic waste have been

chosen as avoided burdens for all the plastic-based wastes, while those related to landfilling of biodegradable waste have been chosen as avoided burdens only for biomass-based wastes, then excluding the natural biomass (RIL1, WOOD1 and WOOD2).

Table 6. Life Cycle Inventory table generated by the FBG model, for the gasification process of the selected waste and biomass fuel and with reference to the functional unit

\begin{tabular}{|c|c|c|c|c|c|c|c|c|c|c|c|}
\hline \multirow[b]{3}{*}{ Feedstock } & \multicolumn{11}{|c|}{ Functional unit: $1 \mathrm{kWh}$ of recovered electricity } \\
\hline & \multicolumn{5}{|c|}{ Plastics } & \multicolumn{5}{|c|}{ Biomass } & \multirow{2}{*}{$\begin{array}{c}\begin{array}{c}\text { Co- } \\
\text { fuel } \\
\text { Plasmi } \\
\text { x+RIL3 }\end{array} \\
\end{array}$} \\
\hline & PE & GS3 & Neolite & Plasmix & PDF & RIL1 & RIL2 & RIL3 & $\begin{array}{c}\text { WOOD } \\
1\end{array}$ & $\begin{array}{c}\text { WOOD } \\
2\end{array}$ & \\
\hline IN (kg) & 0.61 & 0.59 & 0.88 & 0.64 & 1.16 & 1.54 & 1.42 & 1.55 & 2.18 & 1.84 & 0.86 \\
\hline \multicolumn{12}{|c|}{ DIRECT BURDENS } \\
\hline \multicolumn{12}{|c|}{ Consumptions } \\
\hline $\begin{array}{r}\text { Activated } \\
\text { Carbon (g) }\end{array}$ & 0.31 & 0.29 & 0.44 & 0.32 & 0.58 & 0.77 & 0.71 & 0.78 & 1.09 & 0.92 & 0.43 \\
\hline $\begin{array}{r}\text { Hydrated } \\
\text { lime }(\mathrm{g}) \\
\end{array}$ & 4.0 & 3.8 & 5.7 & 4.1 & 7.5 & 10.0 & 9.2 & 10.1 & 14.2 & 12.0 & 5.6 \\
\hline \multicolumn{12}{|c|}{ Residues } \\
\hline $\begin{array}{l}\text { Cyclone } \\
\text { ashes (g) }\end{array}$ & 89.6 & 59.5 & 72.4 & 22.9 & 79.3 & 26.2 & 86.2 & 99.3 & 53.2 & 27.2 & 46.5 \\
\hline $\begin{array}{r}\text { APC residues } \\
(\mathrm{g})\end{array}$ & 4.3 & 4.1 & 6.1 & 4.4 & 8.1 & 10.8 & 9.9 & 10.9 & 15.3 & 12.9 & 6.0 \\
\hline \multicolumn{12}{|c|}{ Direct air emissions } \\
\hline $\mathrm{CO}_{2 \text { fossil }}(\mathrm{kg})$ & 1.60 & 1.63 & 2.12 & 1.81 & 2.23 & - & - & - & - & - & 1.69 \\
\hline $\mathrm{CO}_{2 \text { bio }}(\mathrm{kg})$ & - & - & - & - & - & 2.54 & 2.72 & 2.72 & 2.92 & 2.76 & 0.54 \\
\hline $\mathrm{HCl}(\mathrm{mg})$ & 0.11 & - & 91.7 & 3.4 & 31.7 & 57.9 & - & 12.8 & 9.1 & 8.8 & 5.2 \\
\hline $\begin{array}{r}\mathrm{PM}_{<2.5 \mu \mathrm{m}} \\
(\mathrm{mg}) \\
\end{array}$ & 6.1 & 7.6 & 58.9 & 12.1 & 71.4 & 15.4 & 17.0 & 69.7 & 8.7 & 16.6 & 18.9 \\
\hline $\mathrm{SO}_{x}(\mathrm{mg})$ & - & - & 87 & 63 & 120 & 5 & - & - & 102 & 622 & 84.3 \\
\hline $\mathrm{Sb}(\mathrm{mg})$ & 0.002 & 0.009 & 0.31 & $3.4 \mathrm{E}-04$ & 0.013 & 0.03 & 0.008 & 1.10 & - & - & 0.24 \\
\hline As (mg) & 0.0004 & 0.0004 & 0.001 & 0.001 & 0.001 & - & 0.005 & 0.001 & - & - & 0.001 \\
\hline $\mathrm{Cd}(\mathrm{mg})$ & 0.001 & 0.001 & 0.02 & 0.003 & 0.002 & 0.001 & 0.001 & 0.006 & - & - & 0.004 \\
\hline $\mathrm{Cr}(\mathrm{mg})$ & - & - & 0.87 & 0.06 & - & - & 0.02 & 0.05 & - & - & 0.07 \\
\hline $\mathrm{Fe}(\mathrm{mg})$ & - & $7-$ & 4.1 & 1.8 & 1.5 & & 1.81 & - & - & - & 3.1 \\
\hline $\mathrm{Cu}(\mathrm{mg})$ & - & - & 11.5 & 0.11 & 0.03 & - & 0.0003 & 0.02 & - & - & 0.09 \\
\hline $\mathrm{Pb}(\mathrm{mg})$ & 0.15 & 1.36 & 7.5 & 0.21 & 0.84 & - & 0.02 & 0.44 & - & - & 0.26 \\
\hline $\mathrm{Hg}(\mathrm{mg})$ & 0.0004 & 0.0004 & 0.001 & 0.001 & 0.001 & 0.001 & 0.001 & 0.001 & - & - & 0.0008 \\
\hline $\mathrm{Tl}(\mathrm{mg})$ & 0.002 & 0.001 & 0.002 & 0.002 & 0.003 & 0.0001 & 0.004 & 0.003 & - & - & 0.002 \\
\hline $\mathrm{Zn}(\mathrm{mg})$ & - & - & - & 0.04 & - & - & - & - & 0.4 & 0.4 & 0.03 \\
\hline $\mathrm{NO}_{\mathrm{x}}(\mathrm{mg})$ & 42.9 & 42.1 & 55 & 44.5 & 76.6 & 217 & 99 & 101 & 0.06 & 119 & 56.9 \\
\hline $\mathrm{NH}_{3}(\mathrm{mg})$ & 0.02 & 0.02 & 0.03 & 0.02 & 0.04 & 0.10 & 0.05 & 0.05 & $3 \mathrm{E}-05$ & 0.07 & 0.03 \\
\hline $\mathrm{PCDD} / \mathrm{F}(\mathrm{ng})$ & 0.004 & 0.004 & 0.006 & 0.004 & 0.007 & 0.02 & 0.009 & 0.01 & $6 \mathrm{E}-06$ & 0.01 & 0.05 \\
\hline \multicolumn{12}{|c|}{ AVOIDED BURDENS } \\
\hline Landfilling & 0.61 & 0.59 & 0.88 & 0.64 & 1.16 & - & 1.42 & 1.55 & - & - & 0.86 \\
\hline
\end{tabular}


$(\mathrm{kg})$

An analysis of normalised results for all the impact categories considered in the ILCD 2011 (version EU-27) methodology suggests focusing the attention on the midpoint categories of Climate Change, Particulate Matter, and Human Toxicity. Figure 8 reports LCIA results in terms of kg of carbon dioxide equivalent, for the gasification of the main fuels: it is evident the huge impact of the treatment of plastics waste, and the importance of avoided impacts related to the missed utilisation of landfill in the case of biomass waste gasification. PDF shows the worst performance since its gasification has a low energy efficiency ( $C G E=0.69)$, and then higher amounts of feedstock are required for the production of $1 \mathrm{kWh}$ of electricity.

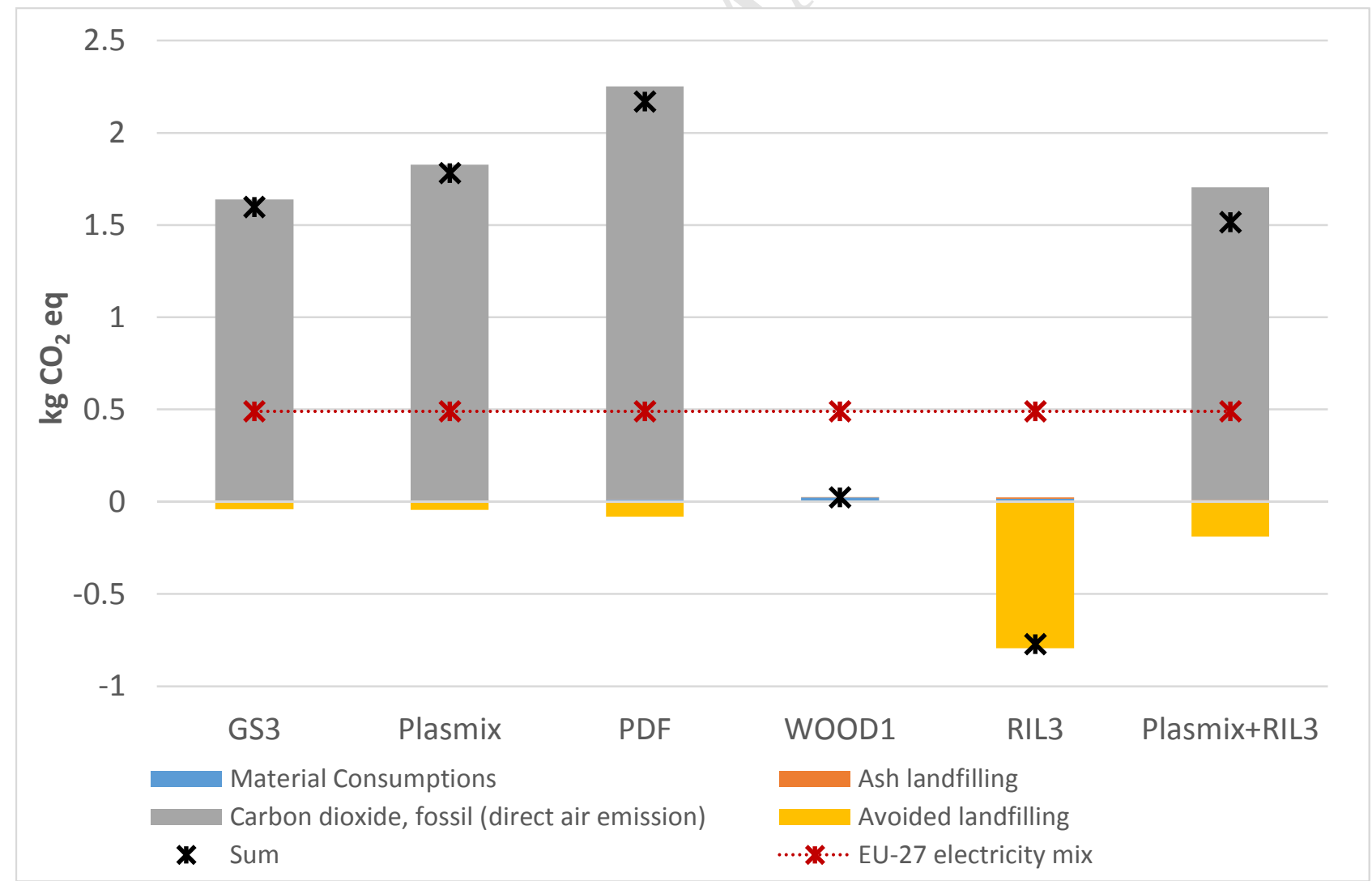

Figure 8. LCIA results for the gasification of some of the analysed wastes, with reference to the "Climate change" impact category, and compared with those associated to the European electricity mix. 
RIL3 indicates the largest savings thanks to the avoided impacts from released biogas from landfilling of biodegradable waste. This scenario also gas the best environmental performance in terms of kg of PM 2.5 equivalent, as showed by Figure 9, even though gasification of this feedstock generates a remarkable direct impact related to the emissions of particulates into the

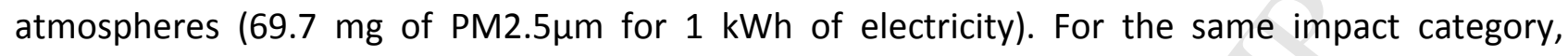
gasification of plastic wastes shows considerably better performances, both in terms of generated and avoided impacts, mainly because of the avoided release of particulate and sulphur dioxide emissions during landfill operations.

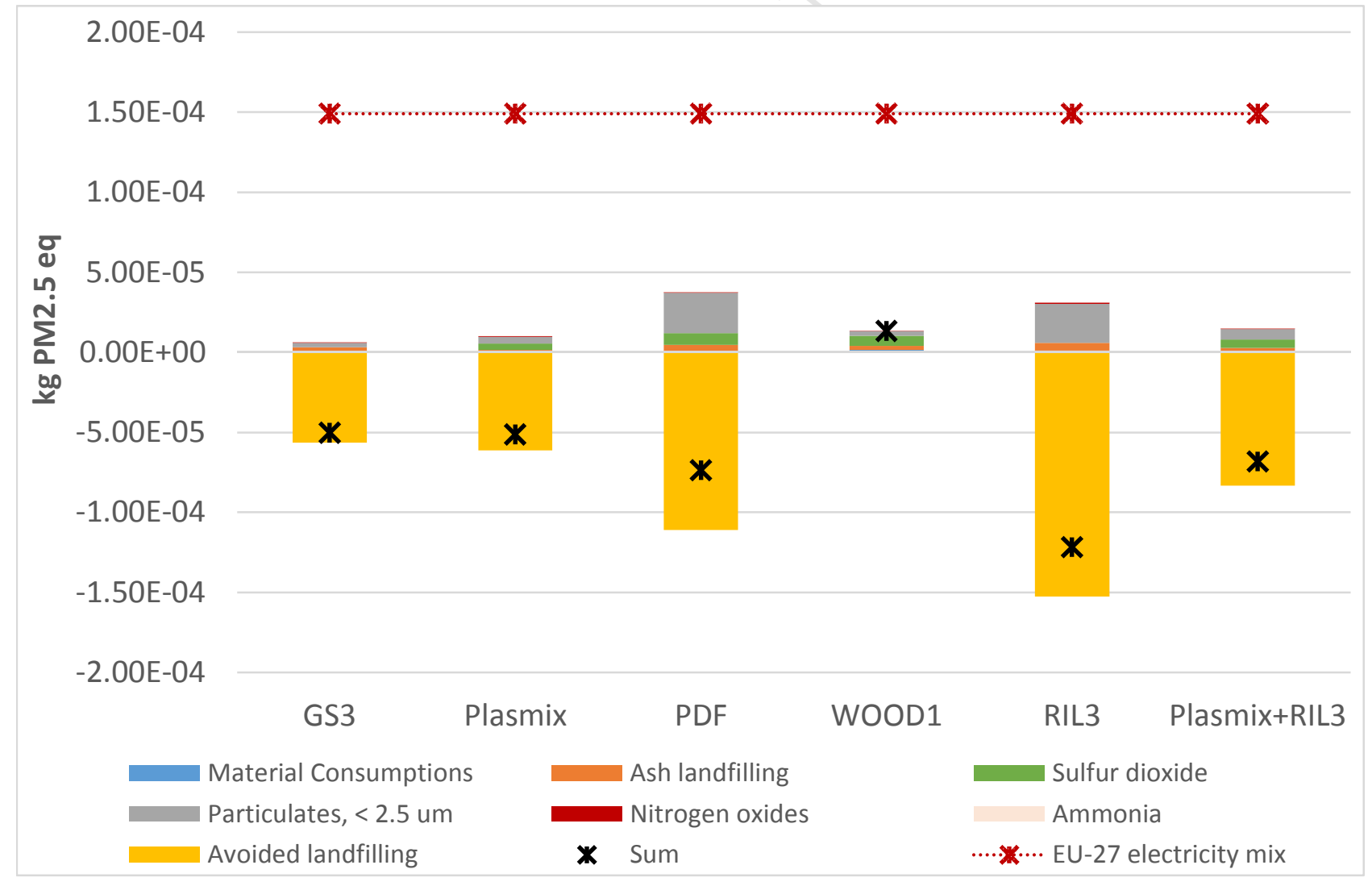

Figure 9. LCIA results for the gasification of some of the analysed wastes, with reference to the "Particulate matter" impact category, and compared with those associated to the European electricity mix. 
This behaviour is confirmed (Figure 10) in terms of "Human toxicity, cancer effects", for which biomass waste gasification has the highest impacts. Higher avoided impacts related gasification of plastic waste are associated with the higher avoided emissions of arsenic in water, mercury in air, and zinc in soil during landfilling operations.

For the same impact category, Plasmix and RIL3 are negatively affected by direct air emissions of chromium (with an average value of $0.06 \mathrm{mg}$ for $1 \mathrm{kWh}$ of electricity). Highest lead air emissions of GS3 (1.36 mg of lead for $1 \mathrm{kWh}$ of electricity) negatively affect the performance for "Human toxicity, non-cancer effects" category. Similar observations can be done for PDF, WOOD1 and RIL3, which show strong contributions due to the air emissions of lead, zinc and mercury. The role of avoided impacts appears less crucial in this impact category. The strong contributions of direct air emissions for human toxicity categories relate to the higher TCs of metals in syngas for PDF but also for Plasmix and RIL3, for both gasification or co-gasification modes (Figure 5). It is noteworthy that data reported in Figures 8-10 suggest better environmental performances of the gasification of all waste, when compared to the production of $1 \mathrm{kWh}$ by the European electricity mix. The only exception is that of the GWP, which is strongly affected by the fossil origin of plastic wastes, and, on the other hand, by the increased fraction of non-fossil energy sources (biomass, solar, wind, nuclear, hydroelectric) in the European electricity mix. 


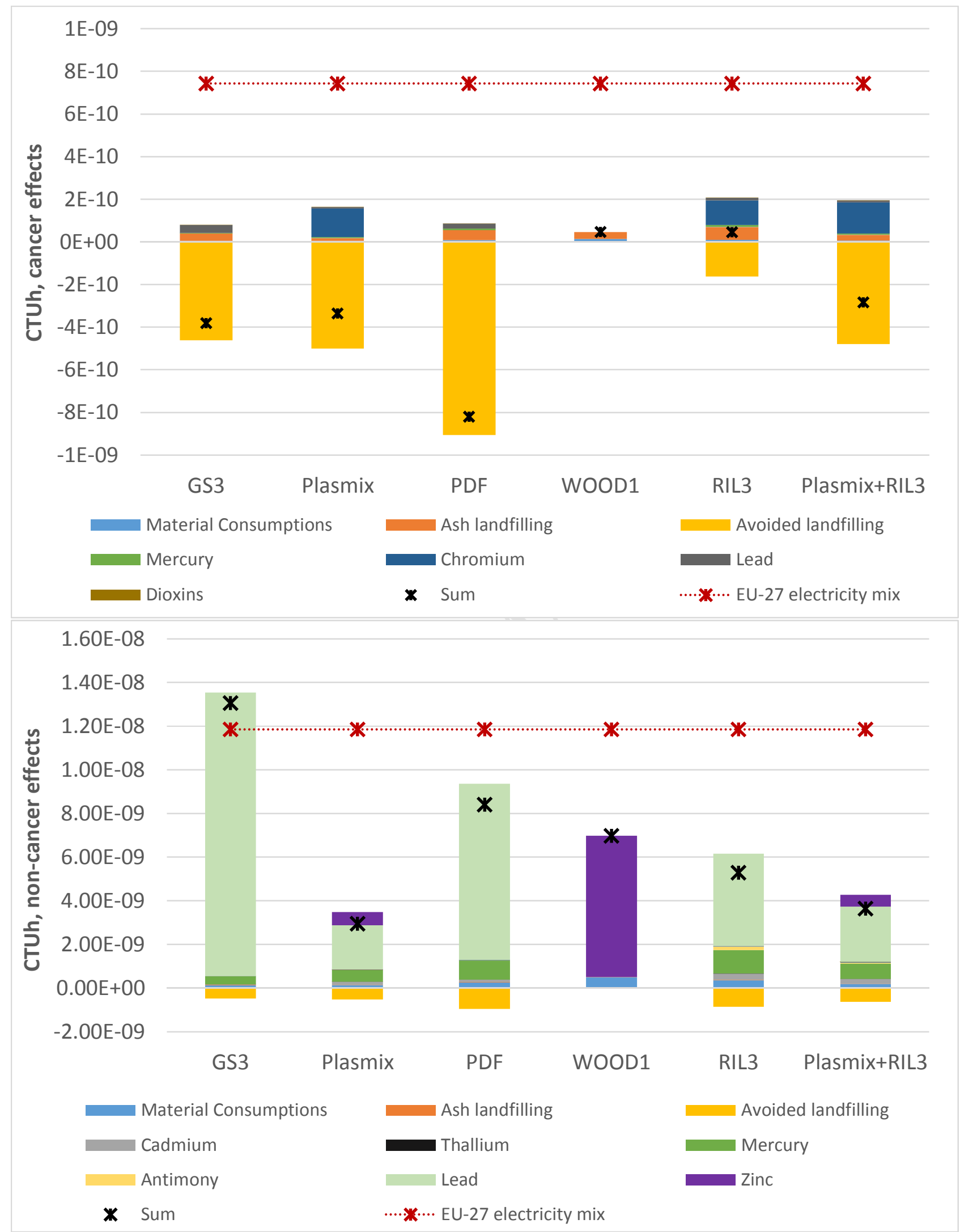

Figure 10. LCIA results for the gasification of some of the analysed wastes, with reference to the "Human toxicity, cancer effects" (up) and "Human toxicity, non-cancer effects" (bottom) impact categories. Data have been compared with those associated to the European electricity mix. CTUh = Comparative Toxic Unit for humans. 
A sensitivity analysis for an LCA study is generally carried out by changing different parameters in their reasonable range of variation and/or comparing possible different scenarios $[22,52]$. In this study, the situation is different since the data set of the reported experimental activity has been used also for implementing the sensitivity analysis. Therefore, the analysis was limited to the effects associated with only two parameters. The first is ER, the most important operating parameter of waste gasification process $[2,4]$, since it strongly affects the syngas composition (and then, its LHV and tar content) and cold gas efficiency of the process. The second parameter is the net electrical efficiency of the ORC, which relates to the final stage of syngas utilization for energy production. The effect of ER on the main model parameters is reported in Table 7, which compares the model results as obtained in the base case (when an average value of ER has been considered) with those obtained by means of a re-determination of TCs and CCs based on the specific experimental results for ER values, at the extremes of their range of variation (Table 3). Figure 11 reports instead the LCIA results in terms of a variation factor VF [11], defined as the ratio between the result for the changed parameter in the sensitivity analysis and that estimated for the base case. Then, $\mathrm{VF}=1$ indicates no variation; some variations occur when $\mathrm{VF}$ is $<1$ or $\mathrm{VF}>1$; and a negative value of VF changes the potential impact from positive to negative or vice-versa. Data in Table 7 and Figure 11 suggest that the assumption of an average value of ER has limited effect on the final results, even though some notable exceptions in terms of Human Toxicity can be seen. The same figure reports also the data obtained by changing the value of the net electrical efficiency of ORC from the conservative value of $17.7 \%$ assumed in the base case to those of $20 \%$ and $22 \%$, which can be better applied to medium-large commercial scale plants [53]. The effect seems again not remarkable. 
Table 7. Sensitivity analysis on the effect of equivalence ratio on the main parameters of the implemented model.

\begin{tabular}{|c|c|c|c|c|c|c|c|c|c|c|c|c|c|c|c|}
\hline \multirow[b]{2}{*}{ Feedstock } & \multicolumn{3}{|c|}{ GS3 } & \multicolumn{3}{|c|}{ Plasmix } & \multicolumn{3}{|c|}{ PDF } & \multicolumn{3}{|c|}{ WOOD1 } & \multicolumn{3}{|c|}{ RIL3 } \\
\hline & Min & $\begin{array}{l}\text { Base } \\
\text { Case }\end{array}$ & Max & Min & $\begin{array}{l}\text { Base } \\
\text { Case }\end{array}$ & Max & Min & $\begin{array}{l}\text { Base } \\
\text { Case }\end{array}$ & Max & Min & $\begin{array}{l}\text { Base } \\
\text { Case }\end{array}$ & Max & Min & $\begin{array}{l}\text { Base } \\
\text { Case }\end{array}$ & Max \\
\hline ER, - & 0.23 & 0.25 & 0.27 & 0.24 & 0.25 & 0.27 & 0.26 & 0.27 & 0.31 & 0.28 & 0.28 & 0.33 & 0.21 & 0.3 & 0.31 \\
\hline CGE, - & 0.75 & 0.76 & 0.88 & 0.69 & 0.63 & 0.59 & 0.67 & 0.69 & 0.60 & 0.66 & 0.68 & 0.73 & 0.61 & 0.59 & 0.60 \\
\hline Feedstock IN, kg & 0.6 & 0.59 & 0.51 & 0.57 & 0.64 & 0.67 & 1.2 & 1.16 & 1.34 & 2.26 & 2.18 & 2.04 & 1.36 & 1.55 & 1.38 \\
\hline $\begin{array}{r}\text { TC Carbon to } \\
\text { syngas }\end{array}$ & 0.75 & 0.89 & 0.96 & 0.95 & 0.98 & 0.998 & 0.98 & 0.97 & 0.96 & 0.90 & 0.95 & 1.0 & 0.953 & 0.954 & 0.985 \\
\hline CC Carbon as CO & 0.73 & 0.68 & 0.81 & 0.11 & 0.12 & 0.14 & 0.29 & 0.30 & 0.31 & 0.32 & 0.32 & 0.32 & 0.418 & 0.42 & 0.436 \\
\hline CC Carbon as $\mathrm{CH}_{4}$ & 0.12 & 0.14 & 0.09 & 0.21 & 0.2 & 0.18 & 0.16 & 0.15 & 0.14 & 0.10 & 0.10 & 0.10 & 0.103 & 0.09 & 0.094 \\
\hline CC Carbon as $\mathrm{C}_{\mathrm{n}} \mathrm{H}_{\mathrm{m}}$ & 0.05 & 0.09 & 0.04 & 0.27 & 0.23 & 0.19 & 0.12 & 0.11 & 0.10 & 0.07 & 0.07 & 0.07 & 0.043 & 0.04 & 0.048 \\
\hline CC Carbon as tar & 0 & 0 & 0 & 0.13 & 0.19 & 0.24 & 0.08 & 0.07 & 0.06 & 0.01 & 0.01 & 0.02 & 0.097 & 0.05 & 0.000 \\
\hline $\mathrm{CC}$ Carbon as $\mathrm{CO}_{2}$ & 0.1 & 0.09 & 0.06 & 0.27 & 0.26 & 0.25 & 0.36 & 0.38 & 0.40 & 0.44 & 0.45 & 0.44 & 0.339 & 0.38 & 0.422 \\
\hline
\end{tabular}




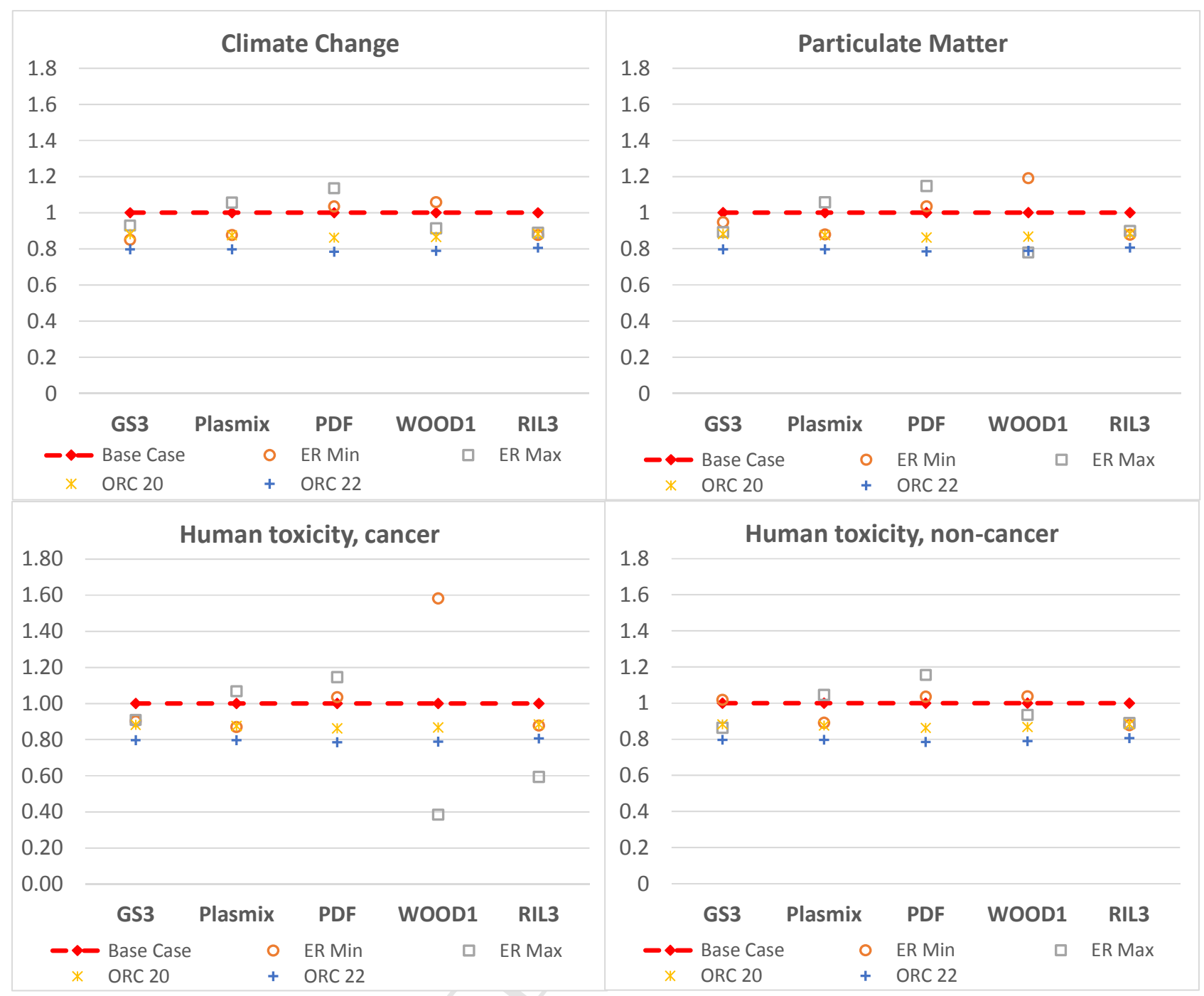

Figure 11. Sensitivity analysis on the effect of ER and net electrical efficiency of the ORC, in terms of a variation factor VF, which transforms the base case value in that related to the modified parameter.

\section{CONCLUSIONS}

A life cycle inventory model for the fluidized bed gasification of a set of waste materials has been developed for the first time, based on an extensive collection of experimental data. All data derive from a pilot scale fluidized bed gasifier, operated under autothermal conditions with ten types of waste and biomass fuels. The implemented model refers to commercial-scale gasification-based waste-to-energy systems, having a "thermal configuration" where the generated syngas is directly 
burned in a mild combustor for production of energy, and the obtained flue gases are cleaned in an air pollution control system.

The study does not develop a descriptive or predictive model for fluidized bed gasification of wastes but implement a life cycle inventory model for fluidized bed gasification of waste, intended to improve the quality of LCA studies in this field.

For each of the selected waste-derived fuels, the model quantifies the main inputs and outputs related to the gasification process: syngas- and process-specific emissions, generated electricity, ashes sent to disposal, and resource consumptions. The model appropriately represents the pilotscale experimental data even though these were obtained for different values of equivalence ratio, fluidizing velocity and air preheating temperature.

The inventory model has been used to assess the environmental performances of some casestudies in an attributional LCA perspective. Potential environmental impacts and performance of the gasification process for the selected waste fuels were assessed with respect to selected impact categories, and compared with those associated with the average European mix for electricity production. The model appears to have limited sensitivity to the values of equivalence ratio and net electrical efficiency of the energy conversion device.

\section{ACKNOWLEDGEMENTS}

The study has been developed in the framework and with the financial support of the project BIOVALUE- PONO3PE_00176 (part of the activities of Smart Power System). Funding from the Danish EUDP grant "SustEnergy" (grant no. 64017-0044) is also acknowledged. 


\section{REFERENCES}

[1] Mahinpey, N., Gomez, A. (2016). Review of gasification fundamentals and new findings: Reactors, feedstock, and kinetic studies. Chem Eng Sci, 148, 14-31.

[2] Arena, U. (2013). Fluidized bed gasification. Chap. 17 in Fluidized-bed technologies for nearzero emission combustion and gasification, F. Scala (Ed.) Woodhead Publishing, p. 765-812. ISBN 978-0-85709-541-1.

[3] Tanigaki, N., Manako, K., Osada, M. (2012) Co-gasification of municipal solid waste and material recovery in a large-scale gasification and melting system. Waste Manage, 32/4, 667-675.

[4] Prins, M.J., Ptasinski, K. J., Janssen, F.J.J.G. (2003). Thermodynamics of gas-char reactions: First and second law analysis. Chem EngSci, 58, 1003 - 1011.

[5] Sikarwar, V.S., Zhao, M., Fennell, P.S., Shah, N., Anthony, E.J. (2017). Progress in biofuel production from gasification. Prog Energ Combust, 61, 189-248.

[6] Puigjaner, L. (2011). Syngas from waste. Emerging technologies. Springer, ISBN 978-0-85729$540-8$.

[7] Kalinci, Y., Hepbasli, A., Dincer, I. (2012). Life cycle assessment of hydrogen production from biomass gasification systems. Int J Hydrogen Energ, 37(19), 14026-14039.

[8] Gómez-Barea, A. and Leckner, B. (2010). Modeling of biomass gasification in fluidized bed. Prog Energ Combust, 36(4), 444-509.

[9] Farzad, S., Mandegari, M. A., Görgens, J. F. (2016). A critical review on biomass gasification, cogasification, and their environmental assessments. Biofuel Res J, 3(4), 483-495. 
[10] Ramachandran, S., Yao, Z., You S., Massier, T., Stimming, U., Wang, C.H. (2017). Life cycle assessment of a sewage sludge and woody biomass cogasification system. Energy, 137, 369-376.

[11] Arena, U., Ardolino, F., Di Gregorio, F. (2015). A life cycle assessment of environmental performances of two combustion- and gasification-based waste-to-energy technologies. Waste Manage, 41.

[12] Fernandez-González, J.M., Grindlay, A.L., Serrano-Bernardo, F., Rodríguez-Rojas, M.I., Zamorano, M. (2017). Economic and environmental review of Waste-to-Energy systems for municipal solid waste management in medium and small municipalities. Waste Manage, 67, 360374.

[13] Arafat, H.A., Jijakli, K., Ahsan, A. (2015). Environmental performance and energy recovery potential of five processes for municipal solid waste treatment. J Clean Prod, 105, 233-240.

[14] Corti, A. and Lombardi, L. (2004). Biomass integrated gasification combined cycle with reduced $\mathrm{CO}_{2}$ emissions: Performance analysis and life cycle assessment (LCA). Energy, 29(12-15), $2109-2124$.

[15] González-García, S., Iribarren, D., Susmozas, A., Dufour, J., Murphy, R.J. (2012). Life cycle assessment of two alternative bioenergy systems involving Salix spp. biomass: Bioethanol production and power generation. Appl Energ, 95, 111-122.

[16] Kimming, M., Sundberg, C., Nordberg, Å., Baky, A., Bernesson, S., Norén, O., Hansson, P.A. (2011). Biomass from agriculture in small-scale combined heat and power plants - A comparative life cycle assessment. Biomass Bioenerg, 35(4), 1572-1581.

[17] Moreno, J., and Dufour, J. (2013). Life cycle assessment of hydrogen production from biomass gasification. Evaluation of different Spanish feedstocks. Int J Hydrogen Energ, 38(18), 7616-7622. 
[18] Puy, N., Rieradevall, J., Bartrolí, J. (2010). Environmental assessment of post-consumer wood and forest residues gasification: The case study of Barcelona metropolitan area. Biomass Bioenerg, 34(10), 1457-1465.

[19] Khoo, H.H. (2009). Life cycle impact assessment of various waste conversion technologies. Waste Manage, 29(6), 1892-1900.

[20] Guest, G., Bright, R.M., Cherubini, F., Michelsen, O., Strømman, A.H. (2011). Life cycle assessment of biomass-based combined heat and power plants: Centralized versus decentralized deployment strategies. J Ind Ecol, 15(6), 908-921.

[21] Dong, J., Tang, Y., Nzihou, A., Chi, Y., Weiss-Hortala, E., Ni, M. (2018). Life cycle assessment of pyrolysis, gasification and incineration waste-to-energy technologies: Theoretical analysis and case study of commercial plants. Sci Total Environ, 626, 744-753.

[22] Astrup, T.F., Tonini, D., Turconi, R., Boldrin, A. (2015). Life cycle assessment of thermal Wasteto-Energy technologies: Review and recommendations. Waste Manage, 37, 104-115.

[23] Susmozas, A., Iribarren, D., Zapp, P., Linßen, J., Dufour, J. (2016). Life-cycle performance of hydrogen production via indirect biomass gasification with CO2capture. Int J Hydrogen Energ, 41(42), 19484-19491.

[24] García, C. A., Morales, M., Quintero, J., Cardona, C. A. (2017). Environmental assessment of hydrogen production based on Pinus patula plantations in Colombia. Energy, 139, 606-616.

[25] Pucker, J., Zwart, R., Jungmeier, G. (2012). Greenhouse gas and energy analysis of substitute natural gas from biomass for space heat. Biomass and Bioenergy, 38, 95-101.

[26] Steubing, B., Zah, R., Ludwig, C. (2011). Life cycle assessment of SNG from wood for heating, electricity, and transportation. Biomass Bioenerg, 35(7), 2950-2960. 
[27] Feng, F., Song, G., Shen, L., Xiao, J. (2017). Environmental benefits analysis based on life cycle assessment of rice straw-based synthetic natural gas in China. Energy, 139, 341-349.

[28] Zhou, H., Qian, Y., Kraslawski, A., Yang, Q., Yang, S. (2017). Life-cycle assessment of alternative liquid fuels production in China. Energy, 139, 507-522.

[29] Ardolino, F., Berto, C., Arena, U. (2017). Environmental performances of different configurations of a material recovery facility in a life cycle perspective. Waste Manage, 68, 662676.

[30] Renó, M.L.G., Olmo, O.A. Del, Palacio, J.C.E., Lora, E.E.S., Venturini, O.J. (2014). Sugarcane biorefineries: Case studies applied to the Brazilian sugar-alcohol industry. Energ Convers Manage, $86,981-991$.

[31] Tonini, D., Astrup, T. (2012). LCA of biomass-based energy systems: A case study for Denmark. Appl Energ, 99, 234-246.

[32] Arena, U., Zaccariello, L., Mastellone, M.L. (2009). Tar removal during the fluidized bed gasification of plastic waste. Waste Manage, 29(2), 783-791.

[33] Arena, U., Zaccariello, L., Mastellone, M.L. (2010). Fluidized bed gasification of waste-derived fuels. Waste Manage, 30(7), 1212-1219.

[34] Arena, U., Zaccariello, L., Mastellone, M.L. (2010). Gasification of Natural and Waste Biomass in a Pilot Scale Fluidized Bed Reactor. Combust Sci Technol, 182(4-6), 625-639.

[35] Arena, U., Chirone, R., Di Gregorio, F., Solimene, R., Urciuolo, M., Zaccariello, L. (2012). A Comparison between fluidized bed combustion and gasification of a mixed plastic waste. 21rst International Conference on Fluidized Bed Combustion, June 3-6 2012, 752-759. ISBN 978-8889677-83-4. 
[36] Di Gregorio, F., Zaccariello, L. (2012). Fluidized bed gasification of a packaging derived fuel: energetic, environmental and economic performances comparison for waste-to-energy plants. Energy, 42, 331-341.

[37] Arena U., Di Gregorio F. (2014). Energy generation by air gasification of two industrial plastic wastes in a pilot scale fluidized bed reactor. Energy, 68, 735-743.

[38] Arena, U., Di Gregorio, F., De Troia, G., Saponaro, A. (2015). A techno-economic evaluation of a small-scale fluidized bed gasifier for solid recovered fuel. Fuel ProcessTechnol, 131, 69-77.

[39] Gómez-Barea, A. (2013). Modelling of fluidized bed gasification processes. Chap. 12 in Fluidized-bed technologies for near-zero emission combustion and gasification, F. Scala (Ed.) Woodhead Publishing, p. 765-812. ISBN 978-0-85709-541-1.

[40] Devi, L., Ptasinski, K.J., Janssen, F.J.J.G., (2005). Pretreated olivine as tar removal catalyst for biomass gasifiers: investigation using naphthalene as model biomass tar. Fuel Process Technol 86, 707-730.

[41] Cavaliere, A., de Joannon, M. (2004). Mild Combustion, Prog Energ Combust 30, 329-366.

[42] Milani, A., Saponaro, A. (2001). Diluted combustion technologies, IFRF Combustion Journal 1, $1-32$.

[43] Lind, T., Hokkinen, J., Jokiniemi, J.K. (2007). Fine particle and trace element emissions from waste combustion - Comparison of fluidized bed and grate firing. Fuel Process Technol, 88(7), 737746.

[44] Zevenhoven, R., Kilpinen, L. (2002). Control of pollutants in flue gases and fuel gases. Available at: http://large.stanford.edu/publications/coal/references/leep/docs/contents.pdf (Accessed: $3^{\text {rd }}$ July, 2018). 
[45] Arena, U., Di Gregorio, F. (2013). Element partitioning in combustion- and gasification-based waste-to-energy units. Waste Manage, 33(5), 1142-1150.

[46] Scala, F. (2013). Fluidized-bed technologies for near-zero emission combustion and gasification (ed.), Woodhead Publishing, ISBN: 978-0-85709-541-1.

[47] ISO, 2006. Environmental Management-Life Cycle Assessment-Requirements and Guidelines, 1st ed.; ISO 14044; 2006-07-01; ISO: Geneva, 2006.

[48] Clift, R., Doig, A., Finnveden, G., (2000). The application of life cycle assessment to integrated waste management. Part 1. Methodology. Trans. IchemE 78/B, 279-287.

[49] EC-JRC. European Commission, Joint Research Centre, Institute for Environment and Sustainability (2012). Characterisation factors of the ILCD Recommended Life Cycle Impact Assessment methods. Database and Supporting Information. First edition. February 2012. EUR 25167. Luxembourg. Publications Office of the European Union.

[50] Mastellone, M.L., Arena, U. (2008). Olivine as a Tar Removal Catalyst during Fluidized Bed Gasification of Plastic Waste. AIChE J, 54/6, 1656-1667.

[51] Basu, P. (2006). Combustion and Gasification in Fluidized Beds. Chapter 12, p.390. CRC Press. Brandrup.

[52] Clavreul, J., Guyonnet, D., Christensen, T.H. (2012). Quantifying uncertainty in LCA modelling of waste management systems. Waste Manage 32, 2482-2495.

[53] Turboden Technology. Technical data available at: http://www.inmis-energy.com/2-0-orctechnology/2-2-the-turboden-orc/2-2-2-efficiency (Accessed on: $13^{\text {th }}$ September 2018). 


\section{ENERGY RECOVERY FROM PLASTIC AND BIOMASS}

\section{WASTE BY MEANS OF FLUIDIZED BED GASIFICATION: A}

\section{LIFE CYCLE INVENTORY MODEL}

Filomena Ardolino ${ }^{1}$, Concetta Lodato ${ }^{2}$, Thomas F. Astrup ${ }^{2}$, Umberto Arena $^{1}$

${ }^{1}$ Department of Environmental, Biological, Pharmaceutical Sciences and Technologies University of Campania "Luigi Vanvitelli", Caserta, Italy.

2 Department of Environmental Engineering, Technical University of Denmark, Bygningstorvet, building 115, 2800 Kgs. Lyngby, Denmark.

\section{APPENDIX A}

\section{Quantification of the fluidizing air stream}

The following relationships quantify the amounts of $\mathrm{O}, \mathrm{N}$, and $\mathrm{H}$, expressed in $\mathrm{g} / \mathrm{h}$, which enter into the reactor with the fluidizing air stream.

$\mathbf{O}[\mathrm{g} / \mathrm{h}]=\mathrm{ER} *\left(\left(\mathrm{~kg} \_\mathrm{C} / \mathrm{MW} \_\mathrm{C} * 2\right)+\left(\mathrm{kg} \_\mathrm{H} /\left(\mathrm{MW} \_\mathrm{H} * 2\right) * 1\right)+(\mathrm{A} .1)\right.$

$\left.\left(\mathrm{kg} \_\mathrm{S} / \mathrm{M} \_\mathrm{S} * 2\right)\right) *\left(\mathrm{MW} \_0\right) * 1000$

$\mathbf{N}[g / h]=\left(E R *\left(\left(k g \_C / M W_{-} C * 1\right)+\left(k g_{-} H /\left(M W_{-} H * 2\right) * 0.5\right)+(A .2)\right.\right.$

$\left.\left.\left(\mathrm{kg} \_\mathrm{S} / \mathrm{M} \_\mathrm{S} * 1\right)\right) / 0.21\right) * 0.79 * 2 * \mathrm{MW} \_\mathrm{N} * 1000$

$\mathbf{H}[\mathrm{g} / \mathrm{h}]=\left(\mathrm{ER} *\left(\left(\left(\mathrm{~kg}{ }_{-} \mathrm{C} / \mathrm{MW} \mathbf{C}_{-} \mathrm{C} * 1\right)+\left(\mathrm{kg}_{-} \mathrm{H} /\left(\mathrm{MW} \_\mathrm{H} * 2\right) * 0.5\right)+(\mathrm{A} .3)\right.\right.\right.$

$\left.\left.\left(\mathrm{kg} \_\mathrm{S} / \mathrm{MW} \_\mathrm{S} * 1\right)\right) / 0.21\right) * \mathrm{MW} \_$Air $) * \%_{\text {mass }} \mathrm{H} * 1000$

Where: 
- kg_C, kg_H and $\mathrm{kg} S \mathrm{~S}$, are the inputs expressed as $\mathrm{kg} / \mathrm{h}$ of $\mathrm{C}, \mathrm{H}$, and $\mathrm{S}$, respectively;

- MW_C, MW_H, MW_N, MW_S and MW_Air are the molecular weights expressed as $\mathrm{kg} / \mathrm{kmol}$ of $\mathrm{C}, \mathrm{H}, \mathrm{N}, \mathrm{S}$ and air, respectively;

- 0.21 and 0.79 are the molar fractions in the air of $\mathrm{O}$ and $\mathrm{N}$, respectively;

- $\%_{\text {mass }} \mathrm{H}$ is the mass fraction of the $\mathrm{H}$ entering as moisture in the air.

According to the standards of EASETECH software, Volatile Solids (VS) have been defined as the fraction of all the input streams that can be converted in gaseous components (i.e. organic matter). VS can enter the reactor with the solid fuel and the fluidizing gas. In particular, $\mathrm{VS}_{\mathrm{air}}$ is the mass of volatile solids that enters the reactor inside the air stream fed from the gas distributor at the bed bottom:

VS $_{\text {air }}[\mathrm{g} / \mathrm{h}]=\mathrm{O}[\mathrm{g} / \mathrm{h}]+\mathrm{N}[\mathrm{g} / \mathrm{h}]+\mathrm{H}[\mathrm{g} / \mathrm{h}]$

while $\mathrm{VS}_{\text {fuel }}$ is the mass of volatile solids that enters the reactor in the solid fuel stream. The latter is reported in Table 2, as obtained from the total fuel mass excluding the inorganic components. 
- The study provides a Life Cycle Inventory model for fluidized bed gasification of wastes

- The model is based on a large amount of experimental data obtained by a pilot-scale gasifier

- Key relationships between process- and waste-specific parameters have been identified

- LCA case-studies have been implemented to show model applicability

- A sensitivity analysis shows that equivalence ratio affects to a limited extent the LCA results 